\title{
POLLEN MORPHOLOGY AND TAXONOMY IN THE LOGANIACEAE
}

\author{
W. PUNT and P. W. LEENHOUTS
}

MS received $15 . \mathrm{V} 1.66$

\author{
Pollen Morphology \\ (W. Punt)
}

The Loganiaceae is a heterogeneous, eurypalynous family with colpate, colporate or porate pollen grains (Erdtman 1952). Some years ago Dr. Leeuwenberg, specialist in the taxonomy of African Loganiaceae, asked the senior author to undertake an investigation of the pollen grains of that family. Unfortunately that was impossible at the time because of other commitments. Later, however, a possibility presented itself for carrying out the investigation in connection with a sojourn at the Palynological Laboratory at Solna. I am much indebted to Professor Erdtman for the invitation to work at this Laboratory, for his approval of the subject, and for many discussions on pollen morphology. I am also much indebted to Dr.Leeuwenberg, Wageningen, and Dr. Leenhouts, Leiden for interesting, carefully determined plant material and for kind advice in taxonomic problems. I also want to express my thanks to all those in the Solna Laboratory, who kindly helped me in various ways during my visit. My work was supported by a grant from the U.S. Atomic Energy Commission to the Palynological Laboratory.

\section{Materials and Methods}

Herbarium material from the following botanical institutions was used: Botanisch Museum en Herbarium, Utrecht (U); Rijksherbarium, Leiden (L); Laboratorium voor Plantensystematiek en -geo- 
grafie, Wageningen (WAG); Naturhistoriska Riksmuseet Stockholm (S). Some specimens from various herbaria were sent to Dr. Leeuwenberg at Wageningen. Besides, some slides from the sporotheke of the Palynological Laboratory Solna (SPL) were used.

The dry material was first boiled in water and then acetolysed (after washing with glacial acetic acid). Acetolysis was carried out in two ways: 1. "Macromethod" (Erdtman 1960). 2. "Micromethod" (Punt 1962). The latter method was used only when a very minute quantity of material was present. The specimens are marked "Mi" or "Ma" in Table 1 according to their treatment. The mounting medium was glycerine jelly. After mounting the slides were sealed off with paraffine wax.

Pollen grains of Labordia tinifolia, Spigelia marilandica, and Anthocleista nobilis were sectioned with a Spencer microtome (model 812 ) in the way described by Praglowski (in Erdtman 1957).

The pollen slides were examined with a Leitz Ortholux microscope (apochromatic objective $96 \times$, A 1.32; eyepiece Periplan GF, $10 \times$ ). The measurements were, as a rule, based on five grains only. The figures thus have no statistical significance. The photomicrographs were taken with a Leitz Ortholux microscope, objective C P1 Oel $160 \times$, A 1.40. Ilford Chromatic, Panchromatic and sometimes Half Tone Chromatic plates were used. Yellow, orange or green filters were used. Original magnification usually $1500 \times$.

The terminology used in this paper follows Erdtman (1943 and 1952) and Fægri and Iversen (1964). In some cases alternatives are given in brackets.

Pollen grains from all genera so far described were examined. In the following list the number of species examined is compared with the total number of species (according to Leenhouts, 1962):

$\begin{array}{cc}\text { Number of species } & \text { Total number } \\ \text { examined } & \text { of spp. }\end{array}$

$\begin{array}{lrrr}\text { 1. Antonia } & 1 & & 1 \\ \text { 2. Adenoplea } & 1 & \text { ca. } & 2 \\ \text { 3. Adenoplusia } & 2 & \text { ca. } & 2 \\ \text { 4. Androya } & 1 & & 1 \\ \text { 5. Bonyunia } & 4 & \text { ca. } & 4 \\ \text { 6. Buddleia } & 13 & \text { ca. } & 110 \\ \text { 7. Cynoctonum } & 3 & & 6 \\ \text { 8. Desfontainia } & 1 & & 1 \\ \text { 9. Emorya } & 1 & & 1\end{array}$

Number of species examined
10. Fagraea
11. Gardneria
12. Gelsemium
13. Geniostoma
14. Gomphostigma
15. Labordia
16. Logania
17. Mitrasacme
18. Mostuea

Total number of spp.
ca. 31
5
3
ca. 30
2
ca. 20
ca. 20
ca. 40
8 
Number of species examined

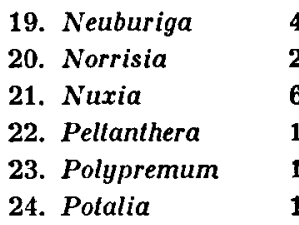

Total number of spp.

ca. 10

2

ca. 20

1

1

1
Number of species examined
Total number of spp.

\section{Pollen descriptions and comments}

25. Relzia 1

26. Sanango 1

1

27. Spigelia 3

ca. 50

28. Strychnos

ca. 200

29. Usteria 1

1

1

\section{ANTONIEAE}

ANTONIA-TYPE

Apertures. - Pollen grains 3-colporate. Colpi sunken. Colpus membrane smooth. Ora (endopori) circular to slightly lolongate, as wide as colpi. Margins of ora thickened (costae).

Shape. - Equatorial view: grains more or less spheroidal (subprolate in Bonyunia superba). Polar view: grains circular.

Exine. - Sexine thicker than nexine. Tectum smooth, usually perforate. In Bonyunia aquatica the bacules (columellae) form a regular pattern (infrastriate-infrareticulate). In the other species of Bonyunia the bacules are inordinate.

\begin{tabular}{|c|c|c|c|}
\hline $\begin{array}{l}\text { Antonia ovata } \\
- \text { Pl. 1: 11-12 }\end{array}$ & $18 \times 19 \mu$ & OSph & \\
\hline Bonyunia antoniifolia & $30 \times 33 \mu$ & OSph & \\
\hline B. aquatica-Pl. 1: 13 & $26 \times 26 \mu$ & Sph & $\begin{array}{l}\text { exine infra-rugulose, muri } \\
\text { straight }\end{array}$ \\
\hline B. minor & $26 \times 24 \mu$ & PSph & \\
\hline B. superba & $28 \times 24 \mu$ & $\mathbf{S P}$ & $\begin{array}{l}\text { bacula distinct, longer at } \\
\text { poles }\end{array}$ \\
\hline Norrisia maior & $13 \times 14 \mu$ & OSph or Sph & \\
\hline N. malaccensis & $17 \times 17.5 \mu$ & OSph or Sph & \\
\hline Usteria guineensis & $22 \times 22 \mu$ & Sph & \\
\hline
\end{tabular}

Antonia, Bonyunia, Norrisia and Usteria have pollen grains of the Antonia-type. Its most striking character is the circular ora accentuated by costae. The exine characters are very similar to those in the Logania-type and the Spigelia-type. Distinct ora are also found in the Gelsemium-type. A smooth perforated tectum is also present in the Logania-, Spigelia-, Potalia- and Geniostoma-types.

Pollen grains of the Antonia-type differ markedly from those in the genus Peltanthera, which undoubtely belong to the Buddleia 
type. This fits with the opinion of Leenhouts (1962) who included Peltanthera in the Buddleieae whereas Hutchinson (1959) placed it in the Antoniaceae. The pollen grains of Oleaceae are entirely different.

Antonia (S. America), Usteria (Africa) and Norrisia (Malesia) show a close resemblance in their pollen. It is remarkable that these small and geographically widely separated genera are so much alike in their pollen grains. The pollen grains of Bonyunia no doubt also belong to this type but they differ slightly in their exine structure. Bonyunia aquatica has short inordinate lirae (rugulate, Fægri \& Iversen, 1964). The other species of Bonyunia differ more or less in their bacules characters. The differences are so small that no attempt for a further division of the genus is made here.

Neither illustrations nor chromosome numbers are published.

\section{BUDDLEIA-TYPE}

\section{BUDDLEIEAE}

\section{Buddleia subtype}

Apertures. - Pollen grains 3-colporate, sometimes 4-colporate. Colpi sunken, ends frequently blunt. Colpus membrane smooth. Ora lalongate (endocolpi), small and indistinct, ends diffuse. Margins not marked by costae.

Shape. - Equatorial view: grains usually subprolate to spheroidal, sometimes oblate-spheroidal. Polar view: grains circular, rarely goniotreme (semiangular or subangular). Grains rather small (longest axis not exceeding $25 \mu)$.

Exine. - Sexine thicker than nexine. Tectum smooth. Bacules (columellae) frequently indistinct.

\begin{tabular}{|c|c|c|c|}
\hline Adenoplea sinuata & $18 \times 18 \mu$ & Sph & $\begin{array}{l}\text { Finely reticulate } \\
\text { (D'Alleizette s.n.) }\end{array}$ \\
\hline- & $17 \times 15.5 \mu$ & PSph & $\begin{array}{l}\text { Not-reticulate } \\
\text { (Afzelius s.n.) }\end{array}$ \\
\hline Adenoplusia axillaris & ca. $15 \mu$ & & Bad material \\
\hline A. uluguruensis & $16 \times 17.5 \mu$ & OSph & \\
\hline Androya decaryi & $20 \times 18.5 \mu$ & PSph & Ora indistinct \\
\hline Buddleia alpina & $18.5 \times 18 \mu$ & Sph or PSph & $\begin{array}{l}\text { Pollen grains sometimes } \\
\text { 4-colporate }\end{array}$ \\
\hline B. americana & $17 \times 18 \mu$ & OSph & Usually 4-colporate \\
\hline B. coriacea & $21 \times 17.5 \mu$ & sP & \\
\hline B. corrugata & $19 \times 15.5 \mu$ & SP & \\
\hline B. elegans & $21 \times 21 \mu$ & Sph & $\begin{array}{l}\text { Slightly angular in polar } \\
\text { view }\end{array}$ \\
\hline
\end{tabular}




\begin{tabular}{|c|c|c|c|}
\hline B. indica-Pl. 1: 1-2 & $20 \times 17.5 \mu$ & SP or PSph & \\
\hline B. madagascariensis & $16 \times 15 \mu$ & PSph & \\
\hline B. marrubiifolia & $17 \times 15.5 \mu$ & PSph & \\
\hline B. salviifolia & $16 \times 13.5 \mu$ & SP & \\
\hline B. stachyoides & $25 \times 21 \mu$ & SP & \\
\hline Nuxia capitala & $15 \times 13 \mu$ & SP & Ora indistinct and narrow \\
\hline N. congesta & $14 \times 15.5 \mu$ & OSph & \\
\hline $\begin{array}{l}\text { N. keniensis (syn. } \\
\text { N. congesta) }\end{array}$ & $17.5 \times 15 \mu$ & SP & \\
\hline $\begin{array}{l}\text { N. oppositifolia (syn. } \\
\text { N. autunesii) }\end{array}$ & $15.5 \times 13 \mu$ & SP & \\
\hline Peltanthera floribunda & $14 \times 14 \mu$ & Sph & \\
\hline Sanango durum & $15.5 \times 16 \mu$ & Sph or Osph & \\
\hline
\end{tabular}

Pollen grains of this subtype occur in most species of Buddleia (sect. Chilianthus excluded), most species of Nuxia and in some small. genera close to Buddleia, viz., Adenoplea, Adenoplusia, Androya, Peltanthera, and Sanango.

\section{Chilianthus subtype}

Apertures. - Pollen grains 3-colporate. Colpi sunken, Colpus membrane smooth. Ora lalongate (endocolpi), small and indistinct, their ends diffuse. Margins without costae.

Shape. -- Equatorial view: grains spheroidal to subprolate. Polar view: grains circular or somewhat goniotreme (semiangular).

Exine. - Sexine thicker than nexine. Grains reticulate. Lumina irregular, small.

\begin{tabular}{|c|c|c|c|}
\hline Buddleia dysophylla & $17 \times 15 \mu$ & Psph or SP & \\
\hline B. glomerata & $17 \times 13 \mu$ & SP & \\
\hline B. saligna - Pl. 1: 3-5 & $16 \times 14 \mu$ & Psph or SP & \\
\hline \multirow[t]{2}{*}{ Gomphostigma virgatum } & $21 \times 21 \mu$ & Sph & (Pont 1718) \\
\hline & $23 \times 25.5 \mu$ & Osph & $\begin{array}{l}\text { (Norlindh \& Weimarck } \\
\text { 4499) }\end{array}$ \\
\hline $\begin{array}{l}\text { Nuxia floribunda (syn. } \\
\text { N. polyantha) }\end{array}$ & $13.5 \times 13.5 \mu$ & Sph & \\
\hline N. verticillata & $15 \times 14 \mu$ & PSph & $\begin{array}{l}\text { reticulum fine, transition to } \\
\text { a perforate tectum }\end{array}$ \\
\hline
\end{tabular}

This subtype is found in several species of Buddleia (sect. Chilianthus), some species of Nuxia and in the small genus Gomphostigma. The Chilianthus subtype closely resembles the Buddleia subtype. The only difference is found in the exine. The pollen grains 
in Gomphostigma differ from those in Buddleia and Nuxia in size only.

\section{EMORYA-TYPE}

Apertures. - Pollen grains 4-colporate (sometimes loxotreme). Colpi sunken. Colpus membrane smooth. Ora lalongate (endocolpi), small, indistinct, their ends diffuse. Margins without costae.

Shape. - Equatorial view: grains subprolate to prolate (sometimes depressed at the poles). Polar view: grains circular to slightly angular.

Exine. - Sexine thicker than nexine. Tectum smooth, perforate. Bacules (columellae) inordinate, comparatively long, sometimes placed in groups.

Emorya suaveolens - Pl. 1:6-10 $\quad 42 \times 32 \mu \quad$ SP-P

Only Emorya belongs to this type. It resembles the Buddleia-type in some characteristics (especially the ora). The number of colpi, however, is different and the bacules are always distinct.

The pollen grains of the Buddleia subtype show some slight variation in their morphological characters. There is some fluctuation in the shape, in the length of the colpi, and in the distinctness of the bacules.

The Chilianthus subtype differs from the Buddleia subtype only by the presence of a reticulum. In some species (e.g. Nuxia verticillata) the reticulum is so fine that it represents a transition to the non-reticulate Buddleia subtype. Therefore it seems better to unite these subtypes with the Buddleia-type.

The Emorya-type differs markedly from the Buddleia-type by its shape, by having four colpi, and by the distinctly visible bacules. Some species in the Buddleia-type also have four colpi ( $B$. alpina and $B$. americana). The most important similarity between both types is in the ora which are small and indistinct. The notable difference in pollen grains between Emorya and Buddleia is in contrast with the overall resemblance between the two genera which made Leenhouts (1962) that they might be united.

The two types have little in common with other Loganiaceous types being considerably different in shape and apertures.

The pollen grains of Peltanthera and Sanango agree in all respects with the Buddleia subtype and do not share any character with the Antonia-type (Antonieae). The genera Adenoplea, Adenoplusia, Androya, and subgenus Nicodemia (Buddleia) also have pollen grains 
which clearly belong to the Buddleia subtype. The relationship of Nuxia with Buddleia is also confirmed by the pollen morphological results.

There is some pollen morphological support to place the Buddleieae near the Scrophulariaceae. The resemblance between their pollen grains and those of Calceolaria is so striking that the latter genus cannot be excluded from the Buddleia-type. The pollen grains of the genera Antirrhinum, Halleria, Linaria, Scrophularia, and Verbascum also have several characters in common with the Chilianthus subtype. The grains of the genera Alonsia, Aplosium, Castilleja, Digitalis, Hebe, Hebenstreitia (Selaginaceae), Hydrotriche, and Paulownia are completely different. This selection of genera is arbitrary and the list is far from complete.

According to Leenhouts (1962) the Buddleieae form a transition between the Loganiaceae and the Scrophulariaceae; they are, however, much easier to separate from the latter than from the former family.

Reduction of the genus Chilianthus to Buddleia is not supported by pollenmorphological evidence. Chilianthus Burch. was united with Buddleia Linn. by Phillips (1946) who was followed by Verdoorn (1963). The following three species belong to this taxon: Buddleia saligna Willd. [syn. Chilianthus arboreus (Linn. f.) A.DC.], Buddleia dysophylla (Benth.) Radlk. [syn. Ch. dysophyllus (Benth.) A.DC.], Buddleia glomerata Wendl. f. [syn. Ch. lobulatus (Benth.) A.DC.]. One species, Buddleia corrugata (Benth.) Phillips, forms a transition between "Chilianthus" and Buddleia. Pollen grains of this species undoubtedly belong to the Buddleia subtype. On the other hand, some Nuxia species ( $N$. polyantha and $N$. verticillata) also have pollen grains of the Chilianthus subtype. This is an indication that Nuxia and Chilianthus may be closely related. In fact, all Chilianthus species have at one time or another been included in Nuxia.

\section{Illustrations}

Erdtman 1952, fig. 144 B, Buddleia japonica Hemsl.

Wang 1960, Tab. LXII, Buddleia lindleyana Forst.

Chromosome numbers (Gadella 1962, 1963, Moore 1947, 1960)

$\begin{array}{lr}\text { Buddleia albiflora Hemsl. } & 2 n=\text { ca. } 114 \\ \text { B. allernifolia Maxim. } & 38 \\ \text { B. americana Linn. } & 76\end{array}$ 
$\begin{array}{ll}B \text {. asiatica Lour. } & 38\end{array}$

$B$. brasiliensis Jacq. $\quad 38$

$B$. candida Dunn. $\quad 76$

B. colvilei Hook. f. et Thoms. ca. 300

$B$. crispa Benth. $\quad 38$

B. davidii Franch. $\quad 76$

B. delavayi Gagnep. ca. 114

B. fallowiana Balf. f. et W. W. Smith - 76

B. farreri Balf. f. et W. W. Smith 38

B. forestii Diels ca. 114

B. globosa Hope $\quad 38$

B. glandiflora Champ. et Schl. $\quad 38$

B. hastata Prain ex Marq. $\quad 38$

B. indica Lam. $\quad 76$

B. japonica Hemsl. $\quad 38$

B. limitanea Smith ca. 114

$B$. lindleyana Fort. $\quad 38$

B. madagascariensis Lam. $\quad 38$

B. nappii Lorenz $\quad 38$

B. nivea Duthie ca. 114

$B$. paniculata Wall. $\quad 38$

B. pterocaulis Jacks. ca. 228

B. salviifolia (Linn.) Lam. $\quad 38$

B. scordioides H. B. K. $\quad 38$

B. stenostachya Reh. et Wils. ca. 114

$B$. sterniana Cotton $\quad 38$

Chilianthus arboreus (Linn. f.) DC. $\quad 38$

Nuxia floribunda Benth. $\quad 38$

\section{SPIgelia-type}

\section{SPIGELIEAE (p. p.)}

Apertures. - Pollen grains 3-colpate or 3-colporate. Colpi wide, not sunken, rather short, and their ends sharp. Colpus membrane absent or present only at the ends of the colpi. Ora congruent with the colpi in Spigelia, nearly congruent in Desfontainia and Polypremum.

Shape. - Equatorial view: grains suboblate or oblate. Polar view: grains goniotreme (semiangular or triangular).

Exine. - Sexine thicker than nexine. Tectum smooth, perforate. Bacules (columellae) short and different in shape and size.

$\begin{array}{lll}\text { Desfontainia spinosa - Pl. 2: 6-7 } & 39 \times 45 \mu & \text { SO or O } \\ \text { Polypremum procumbens } & 24.5 \times 29 \mu & \text { SO } \\ \text { Spigelia anthelmia } & 34 \times 62 \mu & \text { O } \\ \text { S. leiocarpa - P1. 2: 5 } & 45 \times 62 \mu & \text { O } \\ \text { S. martiana } & 29 \times 43 \mu & \text { O }\end{array}$


Spigelia, Desfontainia and Polypremum have pollen grains of this type. Colpus membranes are not present in the investigated species of Spigelia. In Desfontainia and Polypremum, however, a small part of the colpus membrane is present at the ends of the colpi. If there is no colpus membrane, we should speak of an endoaperture. In the genera Desfontainia and Polypremum, where a small part of the colpus membrane is left, it seems reasonable to speak of colporate grains. In Spigelia, where the colpus membrane is completely wanting, it seems better to speak of colpate grains, although, strictly theoretically, these grains are also colporate. The most remarkable character of the Spigelia-type is the absence or, indistinctness of the ora. This character separates the type from all other types in the Loganiaceae. There is, however, a similarity in shape and exine structure with the Logania-type.

The pollen grains of Desfontainia fit completely in the Spigeliatype and do not show any resemblance with the Potalia-type. Inclusion of Desfontainia in the Loganiaceae is supported by this result.

The pollen grains of Polypremum, although less oblate in shape than the grains of Spigelia and Desfontainia, are placed in the same type because of the indistinct lolongate ora.

The taxonomic position of Desfontainia is not clear. Solereder (1892), Klett (1924), and Leenhouts (1962) were doubtful with regard to its affinity. The two last named authors suggested a place near the Potalieae. Pollenmorphological characters are in favour of a place near Spigelia and Polypremum.

The pollen grains of the Rubiaceae-Hedyotideae, to which group Leenhouts (1962) believed Polypremum to be rather closely related, are different.

Pollen of Mitrasacme elata are similar in shape and apertures but differ in exine structure (reticulate).

\section{Mitrasacme elata-type}

Apertures. - Pollen grains 3-colporate. Colpi wide, not sunken, rather short, their ends sharp. Colpus membrane present only at the ends of the colpi. Ora lolongate, indistinct.

Shape. - Equatorial view: grains suboblate or oblate. Polar view: grains goniotreme (angular).

Exine. - Sexine thicker than nexine. Grains reticulate. Muri simplibaculate. Lumina 1-3 $\mu$, smaller towards colpi and poles. 
To the Spigelieae sensu Leenhouts (1962) belong the genera Spigelia, Cynoctonum, Polypremum, and Mitrasacme. Cynoctonum has pollen grains which are characteristic for the Logania type. The species of Mitrasacme show different types of pollen grains. Mitrasacme elata pollen resemble to the Spigelia-type, $M$. indica and $M$. erophila pollen have several characters in common with the Logania-type, and $M$. pygmaea pollen seem to have some similarity with the Gelsemium-type.

Too few species of Mitrasacme-mainly Malesian ones-have been investigated, but as this largely Australian genus is in urgent need of a revision, it seems better to postpone further conclusions. It may be expected that pollen morphology will be of great help in a taxonomic revision.

\section{Illustrations}

Erdtman 1943. Pl. IX fig. 148, 149. Desfontainia spinosa Ruiz et Pavon.

Erdtman 1952. Fig. 145. D. Spigelia anthelmia Linn.

Chromosome numbers (Gadella 1962, Moore 1947)

$\begin{array}{lr}\text { Desfontainia spinosa Ruiz et Pavon } & 2 n=14 \\ \text { Polypremum procumbens Linn. } & 22 \\ \text { Spigelia anthelmia Linn. } & 32 \\ \text { S. marilandica (Linn.) Linn. } & 48 \\ \text { S. splendens Wendl. ex Hook. } & 26\end{array}$

STRYCHNEAE, CYNOCTONUM, LOGANIA AND MITRASACME (p. p.) LOGANIA-TYPE

Apertures. - Pollen grains 3-colporate, rarely 4-colporate. Colpi sunken, their ends often blunt. Colpus membrane smooth. Ora circular to lalongate (endopori to endocolpi), their ends diffuse. Costae may be present.

Shape. - Equatorial view: grains usually suboblate to oblate-spheroidal, sometimes spheroidal or even prolate-spheroidal (Cynoctonum species, Mitrasacme erophila). Polar view: grains goniotreme (subangular, semiangular or sexangular).

Exine: - Sexine mostly thicker than nexine. Tectum smooth, perforate. Some species in Cynoctonum have no perforations. Bacules (columellae) low, capita usually distinct.

Cynoctonum mitreola $\quad 18 \times 18 \mu \quad$ Sph

Mitreola (= Cynoctonum) $15 \times 15.5 \mu \quad$ OSph or Sph petiolata perforations in tectum more crowded in the mesocolpia than in the apocolpia tectum smooth, perforate 


\begin{tabular}{|c|c|c|c|}
\hline Cynoctonum sessilifolia & $16 \times 14 \mu$ & SP or PSph & $\begin{array}{l}\text { bacules indistinct, tectum } \\
\text { not perforate }\end{array}$ \\
\hline C. sphaerocarpum & $15 \times 19 \mu$ & So & $\begin{array}{l}\text { colpi narrow, ora distinct, } \\
\text { circular; rhomboic in } \\
\text { equatorial view }\end{array}$ \\
\hline Gardneria multiflora & & & $\begin{array}{l}\text { pollen grains too young for } \\
\text { measurements }\end{array}$ \\
\hline G. nutans & $23 \times 26 \mu$ & SO or OSph & \\
\hline G. ovata & $21 \times 25 \mu$ & So & \\
\hline Logania floribunda & $20 \times 24 \mu$ & so & $\begin{array}{l}\text { costae faint; perforations in } \\
\text { tectum rather wide }\end{array}$ \\
\hline $\begin{array}{l}\text { L. floribunda (syn. } \\
\text { L. angustifolia) }\end{array}$ & $25 \times 25 \mu$ & Sph & \\
\hline L. hyssopoides & $28 \times 29 \mu$ & OSph & $\begin{array}{l}\text { no costae; grains semian- } \\
\text { gular }\end{array}$ \\
\hline L. linifolia & $23 \times 26 \mu$ & SO or OSph & \\
\hline L. longifolia & $25 \times 25 \mu$ & Sph & \\
\hline L. ovala - Pl. 2: 1-4 & $25 \times 25 \mu$ & Sph & \\
\hline Mitrasacme erophila & $32 \times 29 \mu$ & PSph & ora indistinet \\
\hline Neuburgia celebica & $32 \times 37 \mu$ & so & costae indistinct \\
\hline $\begin{array}{l}\text { Couthovia ( = Neuburgia) } \\
\text { collina }\end{array}$ & $26 \times 31 \mu$ & so & \\
\hline Neuburgia corynocarpa & $26 \times 31 \mu$ & so & \\
\hline $\begin{array}{l}\text { Couthovia ( - Neuburgia) } \\
\text { novocaledonica }\end{array}$ & $25 \times 32 \mu$ & so & \\
\hline Neuburgia lubiflora & $34 \times 41 \mu$ & so & \\
\hline Strychnos angolensis & $23 \times 25 \mu$ & OSph & $\begin{array}{l}\text { ora circular or slightly lo- } \\
\text { longate }\end{array}$ \\
\hline S. chrysophila & $34 \times 39 \mu$ & SO or OSph & \\
\hline S. mellodora & $21 \times 23 \mu$ & OSph & \\
\hline S. nux-vomica & $37 \times 42 \mu$ & SO or OSph & Ora circular; no costae \\
\hline S. parviflora & $19 \times 23 \mu$ & So & \\
\hline S. variabilis & $36 \times 37 \mu$ & OSph & \\
\hline
\end{tabular}

To this type belong the genera Logania, Cynoctonum, Neuburgia, Gardneria and Strychnos, and besides, the species Mitrasacme erophila.

The Logania-type has some characters in common with the Antonia-type as well as with the Spigelia-type. The differences separating it from the Antonia-type are in the ora, from the Spigelia-type in the apertures. The type is easily recognisable by its angular shape and smooth tectum. The grains are usually subangular but sometimes semiangular. All other characters are more or less variable. In equatorial view most grains have a polar axis shorter than the equatorial 
axis (exceptions in Cynoctonum, Mitrasacme). The ora are short and hardly or not longer than the colpus width.

The Geniostoma-type and the Spigelia-type have some pollenmorphological characters in common with the Logania-type.

To the tribe Strychneae belong the genera Strychnos, Gardneria, and Neuburgia. In this circumscription the group is accepted by Solereder (1892), Gandoger (1923), Klett (1924), and Leenhouts (1962). Pollenmorphologically related are the genera Logania, Cynoctonum and some species of Mitrasacme, but it seems that in most other characters they are divergent. No taxonomist has suggested this combination of genera before, though Leenhouts (1962) assumes a closer affinity between the Strychneae and the Loganieae via Neuburgia.

\section{Mitrasacme indica-type}

Apertures. - Pollen grains 3-colporate. Colpi rather wide and long, sunken, their ends blunt. Colpus membrane smooth. Ora circular, indistinct. No costae present.

Shape. - Equatorial view: grains subprolate. Polar view: grains circular.

Exine. - Sexine thicker than nexine. Tectum smooth, perforate. Bacules (columellae) inordinate to slightly rugulate.

$\begin{array}{llll}\text { Mitrasacme indica } & 27 \times 25.5 \mu & \text { SP } & \text { Ora indistinct, no costae } \\ M . \text { neglecta } & 23 \times 25 \mu & \text { OSph } & \text { Ora circular or slightly lo- } \\ & & \end{array}$

The pollen grains of the Mitrasacme indica-type show a distinct morphological resemblance to those of $M$. erophila. The pollen of the latter species, however, undoubtedly belong to the Loganiatype because of their angular shape, whereas those of the former species are circular in polar view.

\section{Mitrasacme pygmaea-type}

Apertures. - Pollen grains 3-colporate. Colpus ends sharp. Colpus membrane smooth. Ora slightly lalongate to circular (endopori), distinct. No costae present.

Shape. - Equatorial view: grains spheroidal or oblate-spheroidal. Polar view: grains circular.

Exine. - Sexine thicker than nexine. Grains reticulate. Lumina fine, smaller than $1 \mu$. Muri simplibaculate.

$\begin{array}{lrl}\text { Mitrasacme pygmaea var. malaccensis } & 27.5 \times 30 \mu & \text { OSph } \\ \text { M. polymorpha } & 31 \times 31 \mu & \text { Sph }\end{array}$


The pollen grains of Mitrasacme polymorpha and M. pygmaea resemble those of the Gelsemium-type in many characters. Mitrasacme grains have, however, a fine reticulum and the longest axis is shorter than in the Gelsemium-type.

The genus Mitrasacme is in urgent need of a revision. Further investigation of the pollen must be postponed until a new revision is available (see p. 478).

Perhaps the examined specimen of $M$. polymorpha also belongs to $M$. pygmaea, as nearly all specimens of $M$. polymorpha proved to be incorrectly determined.

\section{Illustrations}

Wang 1960. Tab. LXII Gardneria multiflora Makino, Strychnos umbellata (Lour.) Merr.

Chromosome numbers (Gadella 1962, 1963, Janaki-Ammal in Moore 1947) Mohrbutter 1936.

$\begin{array}{lr}\text { Strychnos aculeata Soler. } & 2 n=44 \\ \text { S. afzelii Gilg } & 44 \\ \text { S. angolensis Gilg } & 88 \\ \text { S. camptoneura Gilg } & 44 \\ \text { S. congolana Gilg } & 44 \\ \text { S. floribunda Gilg } & 44 \\ \text { S. icaja Baill. } & 44 \\ \text { S. laurina DC. } & 24 \\ \text { S. longicaudata Gilg } & 44 \\ \text { S. malacoclados } \text { C. H. Wright } & 88 \\ \text { S. nigritana Baker } & 44 \\ \text { S. nux-vomica Linn. } & 24 \\ \text { S. soubrensis Hutch. et Dalz. } & 44 \\ \text { S. spinosa Lam. } & 44 \\ \text { S. } \text { splendens Gilg } & 44\end{array}$

\section{Gelsemium-type}

\section{GELSEMIEAE}

Apertures. - Pollen grains 3-colporate. Colpi sunken. Colpus membrane smooth in Mostuea and with some scattered granules in Gelsemium. Ora slightly lalongate (endoporus slightly elongated). The margin of the os is distinctly thickened. Ora not much longer than the colpus width.

Shape. - Equatorial view: grains vary from spheroidal to subprolate. Polar view: grains circular to slightly semiangular, never subangular. Size of the grains is larger than in most other types in the Loganiaceae, usually ca. $40 \mu$.

Exine. - Sexine many times thicker than nexine. Mostuea species are 
striate on the tectum. Gelsemium species are striato-reticulate, simplibaculate. All Mostuea species studied have a tectum perforatum.

$\begin{array}{llll}\text { Gelsemium elegans } & 46 \times 40 \mu & \text { PSph or SP } & \\ \begin{array}{l}\text { G. rankinii } \\ \text { - Pl. 2: 8-10 }\end{array} & 41 \times 41 \mu & \text { Sph } & \\ \text { Mostuea batesii } & 60 \times 51 \mu & \text { SP } & \\ \text { M. brunonis } & 52 \times 50 \mu & \text { PSph } & \text { grains sometimes syncolpate } \\ \text { M. hirsuta } & 46 \times 45 \mu & \text { Sph or PSph } & \\ \text { M. surinamensis } & 46 \times 38 \mu & \text { SP } & \\ \text { - Pl. 2: 11-12 } & & & \end{array}$

Gelsemium and Mostuea have pollen grains of this type

The most remarkable characters of the type are the size of the grains, the distinct bacules (columellae), and the well marked margin of the ora. Distinct ora are also found in the Antonia-type, and, less pronouncedly, in the Logania-type. In the Logania-type, however, the ends of the ora are usually diffuse.

The two genera can be distinguished by their difference in exine structure.

A. Exine striato-reticulate . . . . . . . . . Gelsemium

B. Striae on tectum, tectum perforatum, columellae inordinate . . . . . . . . . Mostuea

Retzia, having indistinct ora, is placed in a type by itself. Several other characters distinguish it also from the Gelsemium-type (see p. 481).

Pollen grains of the Oleaceae, which are thought by some authors to be near the Gelsemieae are different from those of the Gelsemiumtype. Although all genera examined had reticulate grains, the reticulation is quite different. The reticulum in Forestieria, Forsythia, Schrebera, and some other genera resembles the reticulum in the Fagraea ceilanica-type.

Taxonomic relationship between Gelsemium and Mostuea is accepted by most taxonomists, viz. Klett (1924), Leeuwenberg (1961), and Leenhouts (1962).

\section{Illustrations}

Erdtman 1943. Pl. XIV, fig. 237, Gelsemium sempervirens Ait.

Erdtman 1952, fig. 145. C, Gelsemium sempervirens Ait.

Wang 1960. Tab. LXII, p. 117, Gelsemium elegans (Gardn. et Champ.) Benth. 
Chromosome numbers (Moore 1947, Gadella 1962, 1963)

$\begin{array}{lr}\text { Gelsemium sempervirens Ait. } & 2 n=16 \\ \text { Mostuea brunonis Dider. } & 20 \\ \text { M. hirsuta (T. Anders. ex Benth. et Hook.) } & 20 \\ \text { Baill. ex Baker } & \end{array}$

\section{RETZIEAE}

RETZIA-TYPE

Apertures. - Pollen grains 3-colporate. Colpus ends sharp. Colpus membrane densely granulate. Ora indistinct, lalongate (endocolpus). No costae present.

Shape. - Equatorial view: grains oblate-spheroidal to spheroidal. Polar view: grains circular to semiangular.

Exine. - Sexine thicker than nexine. Grains reticulate. Lumina narrower than the muri, muri broad, duplibaculate.

Retzia capensis $\quad 43 \times 45 \mu \quad$ OSph

- Pl. 3: 1-4

To this type belongs Retzia only

The Retzia-type resembles the Gelsemium-type in several characters. The grains are rather large, 3-colporate, and have a coarse reticulum. There are, however, three important differences: 1. Ora indistinct. 2. Colpus membrane densely granulate. 3. Muri duplibaculate. Especially the indistinct ora separate the Retzia-type from the Gelsemium-type. Indistinct ora are also characteristic for both types of the Buddleieae, but in that tribe granulation of the colpus membrane is never found.

The affinities of Retzia are uncertain (Leenhouts, 1962). Leeuwenberg (1964) has the opinion that a relationship to the Solanaceae (Metternichia and Sessea) is less certain than to the Loganiaceae. Within the Loganiaceae Retzia should form a separate tribe near the tribes Antonieae and Buddleieae. Pollen grains of Metternichia and Sessea differ widely from Retzia; those of the Antonia type (Antonieae) are also quite different. The pollen grains of the Buddleieae, however, have some characters in common with the Retzia type.

Neither illustrations nor chromosome numbers published. 


\section{LOGANIEAE p. p. (EXCEPT LOGANIA)}

\section{Geniostoma-type}

Apertures. - Pollen grains porate. Number of pores fluctuates from 3 to 5 and in some rare cases even 6 or 7 pores are present. Pores provided with costae, not protruding, not always in the same plane.

Shape. - Equatorial view: grains oblate to oblate-spheroidal. Polar view: grains distinctly goniotreme (semiangular or subangular).

\section{Geniostoma subtype}

Exine. - Sexine thinner than nexine. Tectum smooth, perforate.

\begin{tabular}{|c|c|}
\hline Geniostoma balseanum & $33 \times 37 \mu$ \\
\hline G. pancheri & $23 \times 31 \mu$ \\
\hline $\begin{array}{l}\text { G. rupestre (syn. G. austra- } \\
\text { lianum) - Pl. 3: 5-7 }\end{array}$ & $22 \times 28 \mu$ \\
\hline $\begin{array}{l}\text { G. rupestre (syn. G. } \\
\text { ligustrifolium) }\end{array}$ & $20 \times 25 \mu$ \\
\hline Labordia hypoleuca & $36 \times 43 \mu$ \\
\hline
\end{tabular}

pollen grains 3-porate, pore diam. ca. $8 \mu$

pollen grains 3-7 porate, pore diam. ca. $4 \mu$

pollen grains 3-5 porate, pore diam. ca. $5 \mu$

pollen grains 3 -porate, pore diam. 2-3 $\mu$

pollen grains 3-5 porate, pore diam. ca. $5 \mu$. Pores not always in the same plane; sometimes vestibulum present

$\begin{array}{llll}\text { L. hedyosmifolia } & 35 \times 41 \mu & \text { So } & \text { pollen grains } 4-5 \text { porate, pore }\end{array}$ diam. 3-4 $\mu$. Pores not always in the same plane; sometimes a small vestibulum present

\section{Darbolia subtype}

Exine. - Sexine thicker than nexine. Grains reticulate. Reticulum very coarse, muri thick, lumina wide.

Labordia helleri According to Selling (1947): pollen grains 3-4-porate (rarely 5-porate), diam. pori ca. $3 \mu$, reticulum but slightly continuous, lumina about 5 (3-8) $\mu$ across.

L. tinifolia var. tenuifolia $32 \times 40 \mu \quad$ SO pollen grains 3-4-porate, pore - Pl. 4: 1-5 diam. ca. $6 \mu$.

Geniostoma and Labordia have pollen grains of this type.

The Geniostoma subtype differs from the Darbolia subtype in exine structure only. Superficially the Geniostoma-type resembles the Potalia-type. Both types are porate, but the Geniostoma-type is 
distinctly angular, whereas the Potalia-type is more or less spheroidal. The similarity is probably a matter of convergence. The exine structure of the Geniostoma-type and the Potalia-type is similar.

Although the Geniostoma-type and the Darbolia subtype differ considerably in surface pattern, their resemblances in shape and apertures are so striking that it seems better to place both as subtypes in one type.

Taxonomically the genera Geniostoma and Labordia are distinctly related. Klett (1924) placed Geniostoma and Labordia in the subtribe Geniostomae. Solereder (1892), Gandoger (1923), and Leenhouts (1962) added Logania, forming the tribe Loganieae. Although a certain similarity between the pollen grains of Logania and the Geniostoma-type is present, it seems better to place Logania next to the representatives of the Strychneae (Strychnos, Gardneria, and Neuburgia).

\section{Illustrations}

Erdtman 1948, fig. 6, Geniostoma rupestre Forst.

Erdtman 1952, fig. 145 B a-d Labordia hedyosmifolia Baill., e Labordia tinifolia A. Gray, f-g Labordia helleri Sherff.

Selling 1947, Pl. 41, fig. 641-643 Labordia hedyosmifolia Baill., 644-645 Labordia molokaiana, 646-649 Labordia waialealae, 650 Labordia helleri Sherff, 651-652 Labordia tinifolia A. Gray.

Chromosome numbers (Gadella 1963)

Geniostoma rupestre, Forst. (syn. G. ligustrifolium) $2 n=40$

\section{Potalia-type}

\section{POTALIEAE}

Apertures. - Pollen grains porate. Number of pores fluctuating between 3 and 5 . When more than 3 pores are present the grains are usually stephanoporate. Sometimes the pori are not in the same plane. Pores protruding. Distinct annulus and costae present.

Shape. - Equatorial view: grains spheroidal or oblate spheroidal. Polar view: grains circular.

Exine. - Sexine thicker than nexine. Grains with a smooth usually perforated tectum.

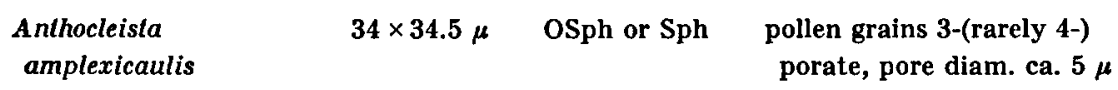


A. djalonensis

A. grandiflora

A. liebrechtsiana

A. madagascariensis

A. nobilis - Pl. 4: 9-10

$33 \times 34 \mu$

ssp. borneensis

Potalia amara

- Pl. 4: 6-8
$32 \mu$ (longest

axis)

$28 \times 28 \mu \quad$ Sph

$30 \times 35 \mu \quad$ SO

$43 \times 46 \mu \quad$ OSph

$33 \times 35 \mu \quad$ OSph

OSph or Sph

$39 \times 40 \mu \quad$ OSph or Sph pollen grains 3-5-porate, pore diam. ca. $4 \mu$, pores not always in the same plane. Tectum not perforate

pollen grains 3-5-porate, pore diam. ca. $5 \mu$. Perforations in tectum crowded, transition to reticulum

pollen grains 3-4-porate, pore diam. 6-7 $\mu$. Perforations in tectum crowded, transition to reticulum

pollen grains 3-4-porate, pore diam. 6-7 $\mu$

pollen grains 3-4 (rarely 5-)porate, pore diam. ca $4 \mu$. Perforations in tectum crowded, transition to reticulum

pollen grains 3-4-porate. Tectum not perforate

pollen grains 3 -(rarely 4-) porate, pore diam. ca. $4 \mu$. Tectum not perforate

Potalia and Anthocleista and the species Fagraea gardenioides ssp. borneensis have pollen grains of this type

The Potalia-type shows a superficial resemblance to the Geniostoma type. Both types are porate, have a smooth tectum, and may have different numbers of pores. This similarity, however, is in my opinion only a convergence. In the Potalia-type the grains are spheroidal or oval in shape, in the Geniostoma-type angular.

It is uncertain which type of the Loganiaceae is morphologically closest to the Potalia-type. The exine structure and the pori of the Antonia-type have some similarity. If we consider reduction of colpi as a morphological evolution in Loganiaceae (see Fagraea), the Antonia-type with its circular ora (endopori) is probably closest to the Potalia-type.

Pollen grains of Potalia and Anthocleista are very much alike. The pori in Potalia amara are somewhat more protuberant than in the Anthocleista species, but this is a gradual difference only. Pollen 
grains of Fagraea gardenioides ssp. borneensis cannot be separated from Anthocleista pollen. They seem to be a perfect link between the Potalia- and the Fagraea-types.

Taxonomists regard Potalia and Anthocleista as distinctly related (Solereder 1892; Gandoger 1923; Klett 1924; Leeuwenberg 1961; Leenhouts 1962). They also suggest a close relationship with $\mathrm{Fa}$ graea. As pollen grains of Fagraea gardenioides ssp. borneensis belong to the Potalia-type and, on the other hand, are distinctly related to some pollen types in Fagraea (F. berteriana-type), this relationship seems justified.

Closer affinity of the Loganiaceae-Potalieae with the Apocynaceae-Tabernaemontanae has been suggested (Leenhouts, 1962); the pollen grains are, however, distinctly different.

\section{Illustrations}

Erdtman 1952, fig. 145 A. Anthocleista parviflora ("parvifolia") (syn. = A. nobilis G. Don; Leeuwenberg, 1961).

Chromosome numbers (Gadella 1961, 1963)

Anthocleista djalonensis Cheval. $2 n=60$

A. liebrechtsiana Wildem. et Durand

60

\section{Fagraea fragrans-type}

Fagraea fragrans subtype

Apertures. - Pollen grains 3-colporate. Colpi narrow, rather short. Ora circular (endopori). Costae present.

Shape. - Equatorial view: grains spheroidal to oblate-spheroidal. Polar view: grains circular.

Exine. - Sexine thicker than nexine. Grains reticulate, slightly striatoreticulate over the entire surface. Lumina small, not exceeding $2 \mu$ in width, muri sharp-edged in the upper part, simplibaculate.

Fagraea fragrans $\quad 17.5 \times 18 \mu \quad$ OSph

- Pl. 6: 5-6

Fagraea crenulata subtype

Apertures. - Pollen grains 3-colporate, nearly porate. Colpi very short and indistinct. Ora circular (endopori). Costae present.

Shape. - Equatorial view: grains oblate-spheroidal. Polar view: grains circular. 
Exine. - Sexine thicker than nexine. Grains slightly striato-reticulate over the entire surface. Lumina angular, muri sharp-edged in the upper part, simplibaculate.

Fagraea crenulata. $\quad 25 \times 27 \mu \quad$ OSph

- Pl. 6: 1-3

\section{Fagraea racemosa subtype}

Apertures. - Pollen grains 3-colporate. Colpi narrow, rather short. Ora circular (endopori). Costae present.

Shape. - Equatorial view: grains oblate-spheroidal to spheroidal. Polar view: grains circular.

Exine. - Sexine thicker than nexine. Grains reticulate. In apocolpia the lumina of the reticulum smaller and distinctly striato-reticulate to striate, in mesocolpia distinctly reticulate. Lumina in mesocolpia rather coarse, muri sharp-edged in the upper part.

$\begin{array}{llll}\text { Fagraea elliplica } & 22 \times 22 \mu & \text { Sph } & \\ \text { F. gracilipes - PI. 6: 7-9 } & 34 \times 34 \mu & \text { Sph } & \\ \text { F. racemosa } & 31 \times 33 \mu & \text { OSph } & \\ \text { F. umbelliflora } & & & \text { pollen grains immature }\end{array}$

\section{Fagraea ceilanica-type}

Fagraea ceilanica subtype

Apertures. - Pollen grains 3-porate. Pori hidden in one lumen of the reticulum. Due to the thickness of the reticulum the costae of the pori are comparatively indistinct.

Shape. - Equatorial view: grains suboblate to spheroidal. Polar view: grains circular.

Exine. - Sexine much thicker than nexine. Grains coarsely reticulate. Lumina wide, irregular, may be ca. $9 \mu$ across, muri simplibaculate or sometimes duplibaculate. In the lower part the bacules (columellae) are stout and not fused, thus forming a fragmentated reticulum. The upper parts (capita) are dilatated laterally and fused with the adjacent capita. These upper parts form a continuous reticulum. The solid muri of this continuous reticulum become thinner towards the top. At the top the muri are sharp-edged.

\begin{tabular}{|c|c|c|c|}
\hline Fagraea acuminatissima & $51 \times 51 \mu$ & Sph & pore diam. 5-6 $\mu$ \\
\hline $\begin{array}{l}\text { F. auriculata ssp. } \\
\text { borneensis }\end{array}$ & $38 \times 40 \mu$ & OSph & pore diam. ca. $4 \mu$ \\
\hline $\begin{array}{l}\text { F. blumei var. blumei } \\
\text { F. ceilanica } \\
\text { - Pl. 5: 5-8 }\end{array}$ & $\begin{array}{l}36 \times 38 \mu \\
52 \times 52 \mu\end{array}$ & $\begin{array}{l}\text { OSph } \\
\text { Sph }\end{array}$ & $\begin{array}{l}\text { pore diam ca. } 3 \mu \\
\text { pore diam. } 4-5 \mu\end{array}$ \\
\hline$F$. fastigiata & $44 \times 47 \mu$ & OSph & pore diam. ca. $4 \mu$ \\
\hline
\end{tabular}




$\begin{array}{lll}\text { F. longillora } & 34 \times 37 \mu & \text { OSph } \\ \text { F. macroscypha } & 40 \times 42 \mu & \text { OSph } \\ & & \\ \text { F. resinosa } & 38 \times 43 \mu & \text { O or OSph } \\ \text { F. tacapala var. gracilis } & 34 \times 38.5 \mu & \text { SO or OSph } \\ \text { F. tubulosa } & 47 \times 51 \mu & \text { OSph } \\ \text { F. woodiana } & 30.5 \times 32.5 \mu & \text { OSph }\end{array}$

pore diam. ca. $4 \mu$ pore diam. 2-3 $\mu$, capita slightly rounded at the top pore diam. 5-6 $\mu$ pore diam. ca. $5 \mu$ pore diam. 5-6 $\mu$. pore diam. ca. $4 \mu$

\section{Fagraea annulata subtype}

Apertures. - Pollen grains 3-porate. Pori circular to oval. Costae pori present. Pori wider than one lumen of the reticulum (ca. 2-5 $\times$ ).

Shape. - Equatorial view: grains oblate-spheroidal. Polar view: grains circular.

Exine. - Sexine thicker than nexine. Grains coarsely reticulate. Lumina wide, can be ca. $6 \mu$ across, muri simplibaculate or sometimes duplibaculate, lower part (columallae) slender, upper part more or less rounded.

$\begin{array}{llll}\text { Fagraea annulata - Pl. 5: } 1 & 48 \times 48 \mu & \text { Sph } & \text { pore diam. ca. } 8 \mu \\ \text { F. carstensensis - Pl. 5:2 } & 41 \times 44 \mu & \text { OSph } & \text { pore diam. 6-8 } \mu \text {, elliptic } \\ \text { F. eymae - Pl. 6: } 4 & 43 \times 46 \mu & \text { OSph } & \text { pore diam. 5-7 } \mu\end{array}$

\section{Fagraea berteriana-TyPe}

Apertures. - Pollen grains 3-(rarely 4-)porate or colporate. If colporate colpi very short, their ends a little blunt. Ora circular (endopori). Costae present.

Shape. - Equatorial view: grains suboblate to oblate-spheroidal. Polar view: grains circular.

Exine. - Sexine thicker than nexine. Grains finely reticulate. Lumina small (less than $1 \mu$ ) and irregular, but all of about the same size, muri simplibaculate, upper part rounded.

\begin{tabular}{|c|c|c|c|}
\hline Fagraea berteriana & $30 \times 34 \mu$ & SO or OSph & pore diam. 3-4 $\mu$ \\
\hline $\begin{array}{l}F . \text { berteriana (syn. } F . \\
\text { schlechteri) - Pl. 5:3-4 }\end{array}$ & $28 \times 31 \mu$ & & $\begin{array}{l}\text { pollen grains colporate, } \\
\text { colpi short }\end{array}$ \\
\hline F. bodenii & $39.5 \times 42.5 \mu$ & OSph & \\
\hline$F$. carnosa & $40 \times 42 \mu$ & OSph & pore diam. 5-6 $\mu$ \\
\hline $\begin{array}{l}\text { F. salticola } \\
\text { - Pl. 6: 10-11 }\end{array}$ & $37 \times 42 \mu$ & OSph & $\begin{array}{l}\text { pollen grains colporate, } \\
\text { pore diam. 5-6 } \mu \text {, colpi } \\
\text { short }\end{array}$ \\
\hline
\end{tabular}

The types and subtypes in the genus Fagraea can be distinguished by their exine patterns. All Fagraea species except one ( $F$. gardenioides ssD. borneensis) have a reticulate exine (the reticulum varies in the different types and subtypes). Points of similarity are found 
in the shape and the apertures. The colporate subtypes have circular ones. The porate ones are probably derived from the colporate subtypes by reduction of the colpi. In favour of this theory is the presence of colporate and porate grains, respectively, in two specimens of $F$. berteriana. Besides, the colpi in the colporate specimen are very short.

The $F$. fragrans subtype, $F$. crenulata subtype and $F$. racemosa subtype are related in their reticulum. In the $F$. fragrans subtype and $F$. crenulata subtype a striato-reticulate pattern is present in the apocolpia as well as in the mesocolpia. A distinct striato-reticulate pattern occurs in the $F$. racemosa subtype in the apocolpia only. The F. crenulata subtype differs from the F. fragrans subtype by very short, indistinct colpi. All subtypes have sharp-edged muri, a character also occurring in the $F$. ceilanica subtype.

The $F$. ceilanica subtype and the $F$. annulata subtype are placed together in one type because both have porate grains and a comparatively coarse reticulum. The typical sharp-edged muri, occurring in the $F$. ceilanica subtype and also present in the $F$. fragrans subtype, are, however, missing in the $F$. annulata subtype, where the muri are rounded in the upper part.

In the $F$. annulata subtype $F$. carstensensis represents a transition to the $F$. ceilanica subtype and $F$. eymae a transition to the $F$. berteriana-type. In $F$. carstensensis the columellae are thicker than in $F$. annulata, but thinner than in the F. ceilanica subtype. $F$. eymae grains have a reticulum with narrower lumina than in $F$. annulata but wider than in the $F$. berteriana-type.

The F. berteriana-type can be distinguished by its fine reticulum. As in the F. annulata subtype the upper part of the muri is rounded. In one specimen of $\boldsymbol{F}$. berteriana the grains are not porate but colporate. The colpi, however, are very short. In $F$. bodenii sometimes. pollen grains with four pores occur.

In pollen morphology there is a close similarity between $F$. berteriana and $F$. gardenioides ssp. borneensis. The pollen grains of the latter species are not reticulate, however, and belong to the Potalia-type (see page 485 ).

It is striking that in Fagraea the species show such a large variation in their pollen characters. This is in contrast with the relative uniformness of most genera in the Loganiaceae (another example is Mitrasacme).

In comparing the different types and subtypes with each other, 
it is possible to distinguish several "evolutionary" trends: 1. Reduction of the colpi. 2. Reduction of the lumina of the reticulum. 3. Enlargement of the lumina of the reticulum.

If tricolporate reticulate pollen grains are regarded as more primitive than porate tectate ones, it follows that the F. fragrans subtype is the most primitive one in Fagraea. This is in accordance with the taxonimic results of Leenhouts (1962). With this subtype as starting point it is possible to draft the following morphological series:
A. F. fragrans $\rightarrow F$. crenulata $\left\{\begin{array}{l}F . \text { ceilanica } \\ F . \text { annulata }\end{array}\left\{\begin{array}{l}\text { Reduction of the colpi } \\ \text { and enlarging of the } \\ \text { lumina }\end{array}\right.\right.$
B. F. fragrans $\rightarrow F$. berteriana $\rightarrow F$.gardenioides $\left\{\begin{array}{l}\text { Reduction of the colpi } \\ \text { and lumina }\end{array}\right.$
C. F. fragrans $\rightarrow F$. racemosa
Reduction of the lumina

Most Fagraea types are completely different from other Loganiaceous types with regard to exine structures. Shape and apertures are similar in the Potalia-type and Antonia-type and to those occurring in the porate pollen types of Fagraea.

Pollen grains in the Apocynaceae-Tabernaemontanae (Tabernaemontana, Voacanga, and Hazunta) are different from those in the Potalieae. This result does not support the suggestion that the Potalieae may be taxonomically related to that tribe of the Apocynaceae. On the other hand, some genera in the Oleaceae (viz. Forestiera, Forsythia, Schrebera, and some other genera) have an exine structure very similar to that met within the $F$. ceilanica-type. The apertures in the Oleaceous genera are, however, quite different.

Professor Rowley of the Department of Botany, University of Massachusetts, Amherst, kindly made some electron micrographs of Fagraea blumei and Fagraea ceilanica. Both species seemed to be identical in their morphological characters when examined with an ordinary light microscope. The replicas distinctly show that the muri of the reticula are different. Both species show a sharp-edged upper part of the muri, but the muri sides in $F$. ceilanica are smooth whereas those in $F$. blumei have small excrescences. Perhaps this character will prove to be of value in a further subdivision of the F. ceilanica type, but the making of replicas required much material and is very time-consuming. For these reasons a further investiga- 
tion of the Fagraea species with the aid of an electron-microscope was not possible.

\section{Illustrations}

Wang 1960, pag. 117, tab. LXII, Fagraea chinensis (syn. F. ceilanica Thunb., Leenhouts, 1962).

Chromosome numbers (Gadella 1963, Mohrbutter 1963)

$\begin{array}{lr}\text { Fagraea ceilanica Thunb. } & 2 n=66 \\ \text { F. fragrans Roxb. } & 12 \\ \text { F. littoralis ( }=\text { F. ceilanica Thunb.) } & 12\end{array}$

PLOCOSPERMA (Gen. inc. sed.)

\section{PlocosPeRMA-TYPE}

Apertures. - Pollen grains 3-colporate. Colpi long.

Shape. - Equatorial view: grains probably subprolate or prolate; polar axis longer than equatorial axis. Polar view: grains circular.

Exine. - Sexine much thicker than nexine. Pollen grains reticulate. Lumina small, ca. $1 \mu$, simplibaculate, bacules high.

Plocosperma microphyllum: pollen grains immature

Morphologically the pollen grains of Plocosperma do not seem related to any pollen type in the Loganiaceae. The apertures differ greatly and the exine structure only shows similarity to that of the grains in the Gelsemium- and Retzia-types. These types, however, differ in too many other characters to suppose a pollen morphological relationship.

\section{Key to pollen types}

1 a Pollen grains reticulate, striate or striato-reticulate . . . . 2

b Pollen grains smooth . . . . . . . . . . . . . . . 15

2 a Pollen grains porate or colpate . . . . . . . . . . . . 3

b Pollen grains colporate . . . . . . . . . . . . . . 7

3 a Reticulum coarse (lumina $>3 \mu$ ) . . . . . . . . . . . 4

b Reticulum fine (lumina $<3 \mu$ ) . . . . . . . . . . . 6

4 a Pollen grains angular in polar view; usually more than three pores . . . . . . Darbolia subtype

b Pollen grains circular in polar view, triporate . . . . . 5 
5 a Upper part of muri sharp-edged. Fagraea ceilanica subtype

b Upper part of muri rounded . . Fagraea annulata subtype

6 a Pollen grains goniotreme with apertures at the angles . . . . Mitrasacme elata-type

b Pollen grains circular in polar view Fagraea berteriana-type

7 a Colpi very short . . . . . . . . . . . . . . . . . . 8

b Length of colpi at least $3 \times$ diameter of ora . . . . . 9

8 a Reticulum fine (lumina $<2 \mu$ )

Upper part of muri rounded . . . Fagraea berteriana-type

b Reticulum coarse (lumina $>2 \mu$ )

Upper part of muri sharp-edged . . Fagraea crenulata subtype

9 a Apocolpia striate. Mesocolpia reticulate . . . . . . Fagraea racemosa subtype

b Pollen grains not striate or if striate, striation not in apocolpia only . . . . . . . . . 10

10 a Colpus membrane densely granulate. Ora indistinct . . . . . . . . . . Retzia-type

b Colpus membrane not granulate or rarely with a few scattered granules (Gelsemium-type) . . 11

11 a Pollen grains with indistinct ora........ .12

b Pollen grains with distinct ora . . . . . . . . . . 13

12 a Pollen grains goniotreme with apertures at the angles in polar view.

Ora lolongate . . . . . . . . Mitrasacme elata-type

b Pollen grains circular in polar view.

Ora lalongate ......... Chilianthus subtype

13 a Ora circular. Grains small, striato-reticulate . . . . Fagraea fragrans subtype

b Ora slightly lalongate . . . . . . . . . . . 14

14 a Pollen grains finely reticulate (lumina $<1 \mu$ ) . . . . . . Mitrasacme pygmaea-type

b Pollen grains striate or striato-reticulate.

Longest axis $>25 \mu$. . . . . . . . Gelsemium-type

15 a Pollen grains porate . . . . . . . . . . . . . 16

b Pollen grains colporate or colpate . . . . . . . . 17

16 a Pollen grains angular in polar view . . Geniostoma subtype

b Pollen grains circular in polar view.

Pores protruding . . . . . . . . . . . Potalia-type

17 a Pollen grains colpate or, if colporate, ora lolongate . . . . . . . . . Spigelia-type 
b Pollen grains colporate. Ora circular or lalongate . . . . 18

18 a Pollen grains angular in polar view . . . . . Logania-type

b Pollen grains circular in polar view . . . . . . . . . . 19

19 a Ora distinct, circular or slightly lolongate . . . Antonia-type

b Ora indistinct, circular or lalongate . . . . . . . . . . 20

20 a Ora circular . . . . . . . Mitrasacme indica-type

b Ora lalongate . . . . . . . . . . . . . . . . 21

21 a Pollen grains small (longest axis not exceeding $25 \mu$ ) 3- or 4- colporate. Bacula short, sometimes indistinct. . . . . . . . . Buddleia subtype

b Pollen grains larger, 4-colporate.

Bacula distinct . . . . . . . . Emorya-type

\section{Table 1. Specimens investigated}

$\mathrm{Ma}=$ Macromethod. $\mathrm{Mi}=$ Micromethod. $\mathrm{NPC}=$ number, position, character of apertures

\begin{tabular}{lll}
\hline Name & Method NPC \\
\hline
\end{tabular}

Antonieae

$\begin{array}{llll}\text { Antonia ovata Pohl } & \text { B. W. 4355; U } & \text { Ma } & 345 \\ \text { Bonyunia antoniifolia Progel } & \text { Ducke 12197; U } & \text { Mi } & 345 \\ \text { B. aquatica Ducke } & \text { Ducke 354; A } & \text { Mi } & 345 \\ \text { B. minor N. E. Brown } & \text { Lasser 1472; VEN } & \text { Mi } & 345 \\ \text { B. superba } \text { R. Schomb. } & \text { Schomburgk 614; P } & \text { Mi } & 345 \\ \text { Norrisia maior Soler. } & \text { Herb. Sandakan 25274; L } & \text { Mi } & 345 \\ \text { N. malaccensis Gardner } & \text { Griffith 3731; S } & \text { Ma } & 345 \\ \text { Usteria guineensis Willd. } & \text { Voorhoeve 106; WAG } & \text { Mi } & 345\end{array}$

Buddleieae

$\begin{array}{llll}\text { Adenoplea sinuala Radlk. } \quad \text { D'Alleizette s.n.; L } & \text { Mi } & 345\end{array}$

Afzelius s.n.; SPL Ma 345

Adenoplusia axillaris Radlk. Hildebrandt 3671; SPL $\quad$ Ma 345

A. uluguruensis Melch. Schlieben 2756 (isotype); P Mi $\mathbf{3 4 5}$

Androya decaryi Perrier $\quad$ Serv. Forest. 8488; P $\quad$ Mi $343 / 345$

Buddleia alpina Oerst. $\quad$ P. H. Allen 3458; U $\quad$ Ma $345 / 445$

B. americana Linn. Rutten \& Rutten-Pekelhar- Ma $\quad 345 / 445$

B. coriacea Remy Brooke 6382; U Ma 345

B. corrugata (Benth.) Phill. Drège s.n. (3618?), anno Ma 345

B. dysophylla (Benth.) $\quad$ Verdcourt s.n., anno 1954; $\quad$ Ma 345

Radlk. K (SPL) 


\begin{tabular}{|c|c|c|c|}
\hline Name & & ethod & NPC \\
\hline $\begin{array}{l}\text { B. elegans Cham. et } \\
\text { Schlecht. }\end{array}$ & Hatschbach 8298; U & Ma & 345 \\
\hline B. glomerala Wendl. 1 . & Coll. ?, S. Africa, anno 1824; S & Ma & 345 \\
\hline B. indica Lam. & Leeuwenberg 3511; WAG & Mi & 345 \\
\hline B. madagascariensis Lam. & De Cary 10061; L & Mi & 345 \\
\hline B. marubiifolia Benth. & Hinckley 3098; U & Ma & 345 \\
\hline B. saligna Willd. & Scott Elliot 356; U & $\mathbf{M i}$ & 345 \\
\hline B. salviifolia (Linn.) Lam. & Stolz 2068; U & $\mathbf{M i}$ & 345 \\
\hline $\begin{array}{l}\text { B. stachyoides Cham. et } \\
\text { Schlecht. }\end{array}$ & R. Klein 560; U & Ma & 345 \\
\hline Emorya suaveolens Torrey & Purpus 4748; BM & $\mathbf{M i}$ & $345 / 445$ \\
\hline $\begin{array}{l}\text { Gomphostigma virgatum } \\
\text { (Linn.) Kuntze }\end{array}$ & Pont 1718; U & Ma & 345 \\
\hline 一 & $\begin{array}{l}\text { Norlindh \& Weimarck 4499; } \\
\text { LD }\end{array}$ & Mi & 345 \\
\hline Nuxia capitata Baker & Bahon 3650 (isotype); P & Mi & 345 \\
\hline $\begin{array}{l}N \text {. congesta R. Brown ex } \\
\text { Fresen }\end{array}$ & Breteler 2573; WAG & $\mathbf{M a}$ & 345 \\
\hline $\begin{array}{l}\text { N. floribunda Benth. [syn. } \\
\text { N. polyantha] }\end{array}$ & Stolz 2068; U & Ma & 345 \\
\hline $\begin{array}{l}N . \text { keniensis T. C. E. Fries } \\
\text { [syn. } N \text {. congesta] }\end{array}$ & $\begin{array}{l}\text { Fries \& Fries } 777 \text { (type); } \\
\text { UPS }\end{array}$ & Ma & 345 \\
\hline $\begin{array}{l}\text { N. oppositifolia (Hochst.) } \\
\text { Benth. [syn. N. antunessii] }\end{array}$ & Baum 29 (type); $\mathbf{S}$ & $\mathbf{M a}$ & 345 \\
\hline N. verticillata Lam. & Johnston s.n., anno 1889; U & Mi & 345 \\
\hline Peltanthera floribunda Benth. & A. E. Lawrence 432; $A$ & $\mathbf{M i}$ & 345 \\
\hline $\begin{array}{l}\text { Sanango durum Bunting et } \\
\text { Duke }\end{array}$ & Wurdack 2018; US & $\mathbf{M i}$ & 345 \\
\hline Spigelieae (p.p.) - & , & & \\
\hline $\begin{array}{l}\text { Desfontainia spinosa } \\
\text { Ruiz et Pavon }\end{array}$ & Leeuwenberg 3507; WAG & $\mathbf{M i}$ & 345 [344] \\
\hline Mitrasacme elata R. Brown & Brass 27227; L & Mi & 343 \\
\hline $\begin{array}{l}\text { Polypremum procumbens } \\
\text { Linn. }\end{array}$ & Kramer \& Hekking 2547; U & Mi & $345[343]$ \\
\hline Spigelia anthelmia Linn. & Jonker-Verhoef \& Jonker 17; U & $\mathbf{M i}$ & 343 \\
\hline S. leiocarpa Benth. & Y. Mexia 6290; U & Mi & 343 \\
\hline S. martiana Cham. & Hatschbach 8458; U & Mi & 343 \\
\hline \multicolumn{2}{|c|}{ Strychneae, Loganieae (p.p.), Mitrasacme (p.p.) } & & \\
\hline $\begin{array}{l}\text { Cynoctonum mitreola (Linn.) } \\
\text { Britt. }\end{array}$ & Smitinand 3565; L & Mi & 345 \\
\hline $\begin{array}{l}\text { Mitreola }(=\text { Cynoctonum) } \\
\text { petiolata Torrey }\end{array}$ & $\begin{array}{l}\text { E. Wall/Fischer s.n., anno } \\
\text { 1933; S }\end{array}$ & Ma & 345 \\
\hline
\end{tabular}




\begin{tabular}{|c|c|c|c|}
\hline Name & & ethod & NPC \\
\hline $\begin{array}{l}\text { Cynoctonum sessilifolia } \\
\text { J. F. Gmelin }\end{array}$ & Vesterland s.n., anno 1889; S & Ma & 345 \\
\hline C. sphaerocarpum Leenh. & $\begin{array}{l}\text { J. \& M. S. Clemens } 29649 \\
\text { (type); L }\end{array}$ & Mi & 345 \\
\hline Gardneria multiflora Makino & Ren Chang Ching 2955; S & Ma & 345 \\
\hline G. nutans Sieb. et Zucc. & Coll. ? 459; L & $\mathbf{M a}$ & 345 \\
\hline G. ovata Wall. & Hohenacker 1445; U & Ma & 345 \\
\hline $\begin{array}{l}\text { Logania angustifolia } \\
\text { R. Brown }\end{array}$ & Watson 23; U & Ma & 345 \\
\hline L. floribunda R. Brown & Constable 7242; U & Ma & 345 \\
\hline L. hyssopoides Nees & Mueller s.n.; U & Mi & 345 \\
\hline L. linifolia Schlecht. & Kaspiew 6; U & $\mathbf{M a}$ & 345 \\
\hline L. longifolia R. Brown & Coll. ? S. Austr.; U & Ma & 345 \\
\hline L. ovata R. Brown & Cunningham 252; $\mathrm{U}$ & Ma & 345 \\
\hline Mitrasacme erophila Leenh. & $\begin{array}{l}\text { Hook. f. \& Thomson s.n., } \\
\text { Mt. Khasia; L }\end{array}$ & Mi & 345 \\
\hline$M$. indica Wight & $\begin{array}{l}\text { Hook. f. \& Thomson s.n., } \\
\text { Malabar; L }\end{array}$ & $\mathbf{M i}$ & 345 \\
\hline M. neglecta Leenh. & Coert $917 ; \mathbf{L}$ & Mi & 345 \\
\hline M. polymorpha R. Brown & Constable 6239 ; U & Mi & 345 \\
\hline $\begin{array}{c}\text { M. pygmaea R. Brown var. } \\
\text { malaccensis (Wight) Hara }\end{array}$ & Bünnemeyer 5770; U & Mi & 345 \\
\hline $\begin{array}{l}\text { Neuburgia celebica (Koord.) } \\
\text { Leenh. }\end{array}$ & Kjellberg 2025; SPL & Ma & 345 \\
\hline $\begin{array}{l}\text { Couthovia }(=\text { Neuburgia }) \\
\text { collina A. C. Smith }\end{array}$ & A. C. Smith 6157; S & Ma & 345 \\
\hline $\begin{array}{l}\text { Neuburgia corynocarpa } \\
\text { (A. Gray) Leenh. }\end{array}$ & A. C. Smith 6330; S & Ma & 345 \\
\hline $\begin{array}{l}\text { Couthovia (= Neuburgia) } \\
\text { novo-caledonica Gilg et } \\
\text { Bened. }\end{array}$ & Däniker 1068; SPL & Ma & 345 \\
\hline Neuburgia tubiflora Blume & Aet 143 (type); L & Mi & 345 \\
\hline Strychnos angolensis Gilg & Welwitsch 4776 (type); LISU & Ma & 345 \\
\hline S. chrysophylla Gilg & Le Testu 9377; P & Ma & 345 \\
\hline S. mellodora S. Moore & Hack 4; FHO & Ma & 345 \\
\hline S. nux-vomica Linn. & Cult. Hort. Bog. I. C. 6; U & Mi & 345 \\
\hline $\begin{array}{l}\text { S. parviflora Spruce ex } \\
\text { Benth. }\end{array}$ & Ducke 1110; IAN & Ma & 345 \\
\hline S. variabilis De Wildeman & A. Carlier 57; BR & $\mathbf{M a}$ & 345 \\
\hline \multicolumn{4}{|l|}{ Gelsemieae } \\
\hline $\begin{array}{l}\text { Gelsemium elegans (Gardn. } \\
\text { et Champ.) Benth. }\end{array}$ & Balansa 1041 ; L & Ma & 345 \\
\hline G. rankinii Small & Godfrey 56366; GB & $\mathbf{M i}$ & 345 \\
\hline Mostuea batesii Baker & Breteler 2750; WAG & Mi & 345 \\
\hline
\end{tabular}




\begin{tabular}{|c|c|c|c|}
\hline Name & & Method & NPC \\
\hline M. brunonis Dider. & Breteler 2331; WAG . & Mi & $245 / 345$ \\
\hline $\begin{array}{l}\text { M. hirsuta (T. Anders. ex } \\
\text { Benth. et Hook.) Baill. ex } \\
\text { Baker }\end{array}$ & Thomas 265; K (SPL) & $\mathbf{M a}$ & 345 \\
\hline M. surinamensis Benth. & Versteeg 878; U & Mi & 345 \\
\hline \multicolumn{4}{|l|}{ Retzieae } \\
\hline Retzia capensis Thunb. & Bos 674; WAG & $\mathbf{M i}$ & 345 \\
\hline \multicolumn{4}{|l|}{ Loganieae (p.p.) } \\
\hline $\begin{array}{l}\text { Geniostoma balseanum Baill. } \\
\text { G. pancheri Baill. }\end{array}$ & $\begin{array}{l}\text { Mackee 5429; L } \\
\text { Däniker 3094; SPL }\end{array}$ & $\begin{array}{l}\mathrm{Mi} \\
\mathrm{Ma}\end{array}$ & $\begin{array}{l}344 \\
344 / 444-744\end{array}$ \\
\hline $\begin{array}{l}\text { G. rupestre Forster (syn. } \\
\text { G. australianum) }\end{array}$ & $\begin{array}{l}\text { Mueller s.n. (Rockhampton } \\
\text { Bay); U }\end{array}$ & $\mathbf{M a}$ & $344 / 544-744$ \\
\hline $\begin{array}{l}\text { G. rupestre Forster (syn. } \\
\text { G. ligustrifolium) }\end{array}$ & H. Powell s.n., 2.IX.1947; U & Ma & 344 \\
\hline $\begin{array}{l}\text { Labordia hedyosmifolia } \\
\text { Baill. }\end{array}$ & $\begin{array}{l}\text { Selling s.n., Hawaii, } \\
\text { 10.IX.1938; SPL }\end{array}$ & $\mathbf{M a}$ & $444 / 544$ \\
\hline L. hypoleuca Degener & Degener 10,000; SPL & Ma & $444 / 544$ \\
\hline L. helleri Sherff & A. A. Heller 2579; BISH & $\mathbf{M a}$ & $344 / 444-644$ \\
\hline $\begin{array}{l}\text { L. tinifolia A. Gray var. } \\
\text { tenuifolia Degener et } \\
\text { Sherff ex Sherff }\end{array}$ & Degener 10272; SPL & Ma & $344 / 444$ \\
\hline \multicolumn{4}{|l|}{ Potalieae } \\
\hline $\begin{array}{l}\text { Anthocleista amplexicaulis } \\
\text { Cheval. }\end{array}$ & Serv. Forest. 7388; P & $\mathbf{M a}$ & $344 / 444$ \\
\hline A. djalonensis Cheval. & Leeuwenberg 3316; WAG & $\mathbf{M i}$ & $344 / 444-544$ \\
\hline A. grandiflora Gilg & Stolz 497; S & Ma & $344 / 444-544$ \\
\hline $\begin{array}{l}\text { A. liebrechtsiana De Wilde- } \\
\text { man et Dur. }\end{array}$ & Breteler 2806; WAG & Mi & $344 / 444$ \\
\hline A. madagascariensis Baker & Humbert 23018; P & Ma & $344 / 444$ \\
\hline A. nobilis G. Don & Leeuwenberg 2322; WAG & $\mathbf{M i}$ & $344 / 444$ \\
\hline $\begin{array}{l}\text { Fagraea acuminatissima } \\
\text { Merr. }\end{array}$ & Jacobs $5633 ; \mathrm{L}$ & Mi & 344 \\
\hline$F$. annulata Hiern & Versteeg 1237 (type); U & Mi & 344 \\
\hline $\begin{array}{l}F . \text { auriculata Jack ssp. } \\
\text { borneensis (Sheff.) Leenh. }\end{array}$ & Cult. Hort. Bog.; U & Mi & 345 \\
\hline $\begin{array}{l}F . \text { berteriana A. Gray ex } \\
\text { Benth. }\end{array}$ & Brass 28140; L & $\mathbf{M a}$ & 344 \\
\hline $\begin{array}{l}F . \text { berteriana A. Gray ex } \\
\text { Benth. (syn. } F . \text { Schlechteri) }\end{array}$ & Däniker 648; SPL & $\mathbf{M a}$ & 345 \\
\hline F. blumei G. Don & Koorders $4321 \mathrm{~b}$; $\mathrm{S}$ & Ma & 344 \\
\hline F. bodenii Wernh. & Pulle $894 ; \mathrm{U}$ & Mi & 345 \\
\hline$F$. carnosa Jack & Cult. Hort. Bog. X.G. 24; L & $\mathbf{M i}$ & 344 \\
\hline
\end{tabular}




\begin{tabular}{|c|c|c|c|}
\hline Name & & Method & NPC \\
\hline F. carstensensis Wernh. & $\begin{array}{l}\text { P. v. Royen \& Sleumer } \\
\text { 7755; L }\end{array}$ & Mi & 344 \\
\hline F. ceilanica Thunb. & Hulstijn $363 ; \mathbf{L}$ & Mi & 344 \\
\hline F. crenulata Clark & Hort. Bot. Singapore 1904; L & $\mathbf{M i}$ & 345 \\
\hline F. elliptica Roxb. & Hort. Bog. 592; L & $\mathbf{M a}$ & 345 \\
\hline F. eymae Backer & Eyma 4330 bis (type); L & $\mathrm{Ma}$ & 344 \\
\hline F. fastigiata Blume & $\begin{array}{l}\text { Coll. ? Herb. No 908.127-108; } \\
\text { L }\end{array}$ & Ma & 344 \\
\hline F. fragrans Roxb. & Kostermans 8955; L & Ma & 345 \\
\hline $\begin{array}{l}F, \text { gardenioides Ridl. ssp. } \\
\text { borneensis Leenh. }\end{array}$ & $\begin{array}{l}\text { Sarawak Museum } 2508 \\
\text { (type); L }\end{array}$ & Mi & 344 \\
\hline F. gracilipes A. Gray & Robins 570; L & Mi & 345 \\
\hline F. involucrata Merr. & Sandakan Herb. 16380; L & Ma & 344 \\
\hline F. aff. longiflora Merr. & Elmer $9159 ; \mathbf{L}$ & Ma & 344 \\
\hline F. macroscypha Baker & ?; L & Ma & 344 \\
\hline$F$, racemosa Jack ex Wall. & Santos 4256 ; L & $\mathrm{Ma}$ & 345 \\
\hline F. resinosa Leenh. & Hallier 3162 (type); L & $\mathbf{M a}$ & 344 \\
\hline F. salticola Leenh. & Hoogland \& Schodde 7425; L & Mi & 344 \\
\hline $\begin{array}{l}\text { F. tacapala Leenh. ssp. } \\
\text { gracilis Leenh. }\end{array}$ & Kjellberg 1521 a (type); S & Ma & 344 \\
\hline F. tubulosa Blume & Coll. ? (type); L & Mi & 344 \\
\hline F. umbelliflora Gilg et Bened. & Ledermann 9614 (type); L & Mi & 345 \\
\hline F. woodiana F. v. Muell. & J. J. F. E. de Wilde 1202; L & Mi & 344 \\
\hline Potalia amara Aubl. & Versteeg 323; U & Mi & $344 / 444$ \\
\hline \multicolumn{4}{|l|}{ Plocosperma (gen. inc.sed.) } \\
\hline $\begin{array}{l}\text { Plocosperma microphyllum } \\
\text { Baill. ex Soler. }\end{array}$ & Galeotti (type); P [SPL] & Ma & 343 \\
\hline
\end{tabular}

Botanisch Museum en Herbarium, Utrecht, Netherlands. 

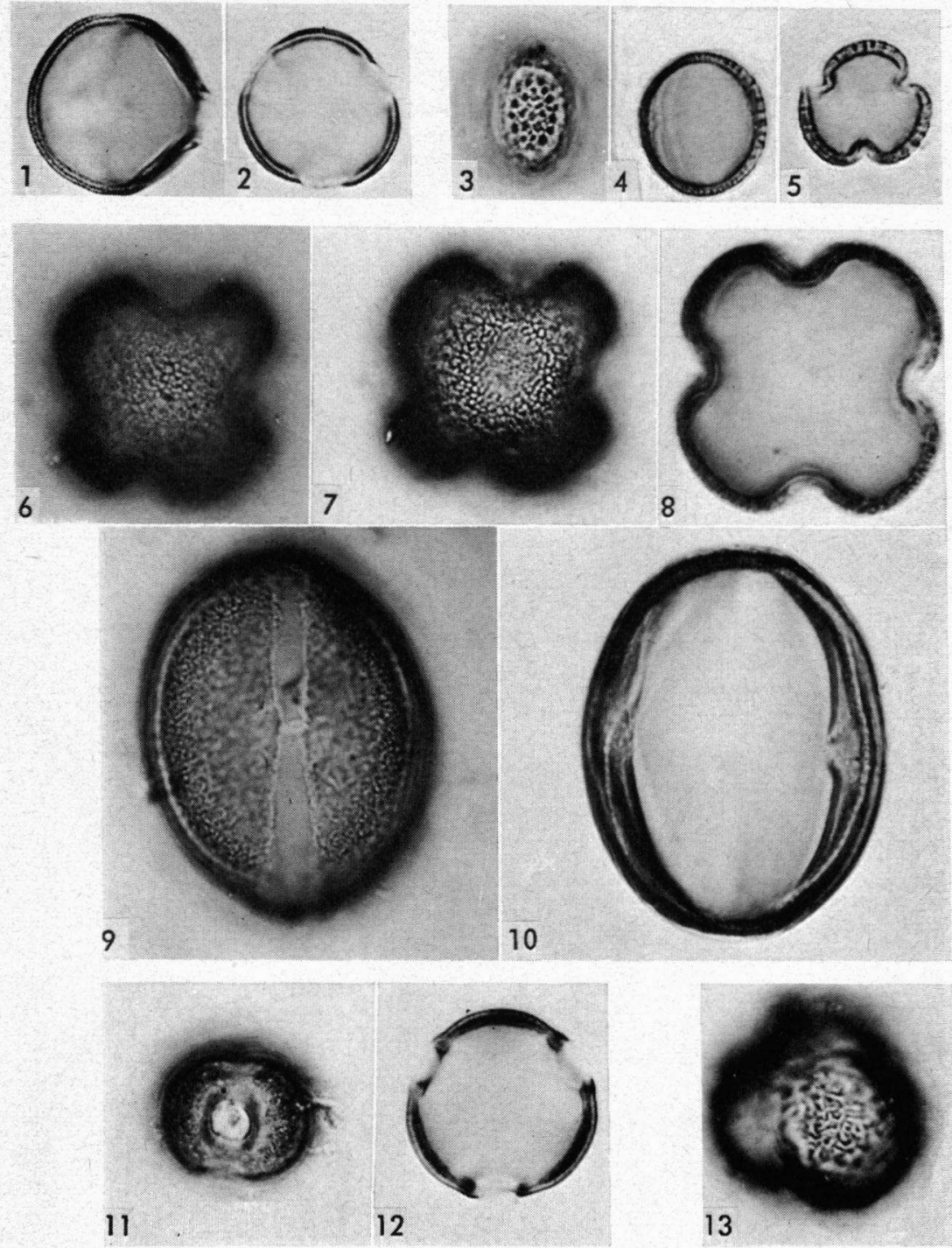

Pl. 1. 1-2, Buddleia-type, Buddleia subtype (Buddleia indica).-3-5, Buddleia-type, Chilianthus subtype (Buddleia saligna).-6-10, Emorya-type (Emorya suaveolens). 11-13, Antonia-type. 11-12 (Antonia ovata). 13 (Bonyunia aquatica). $\times 1200$. 

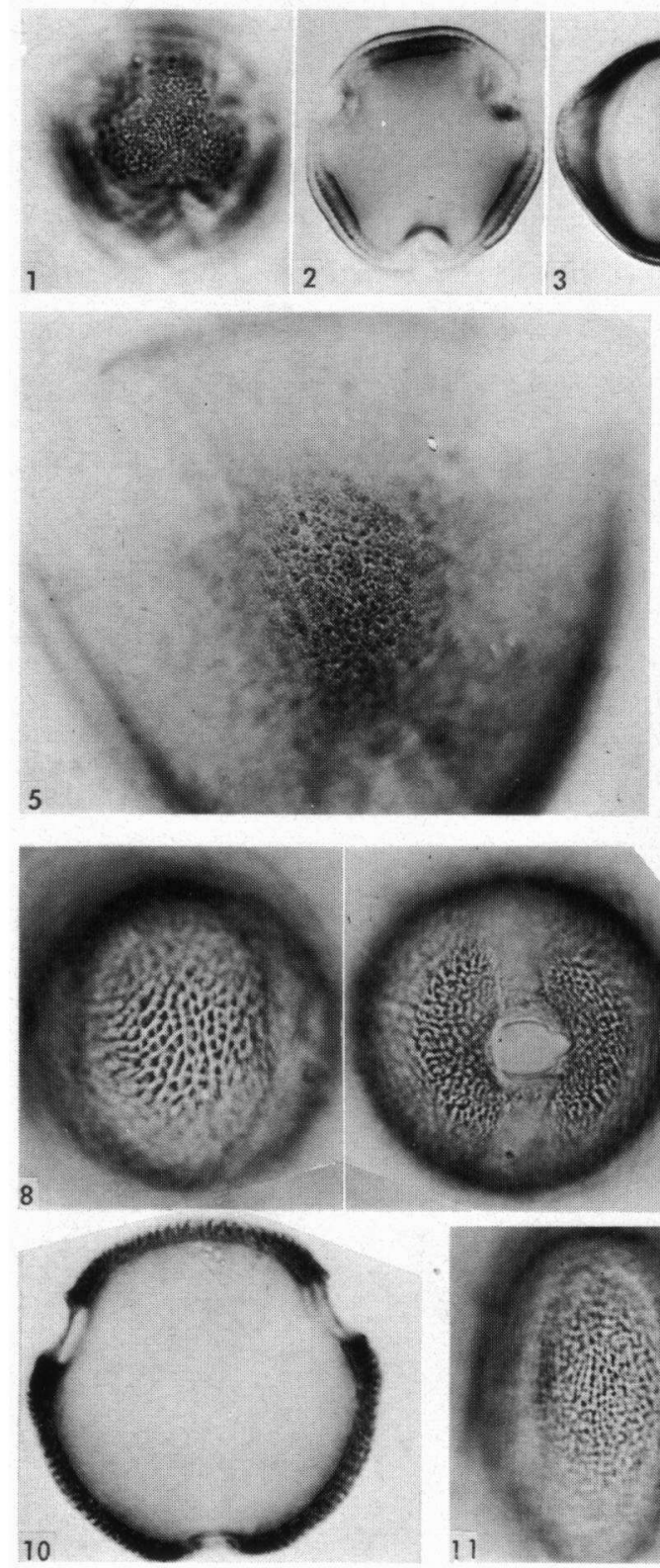
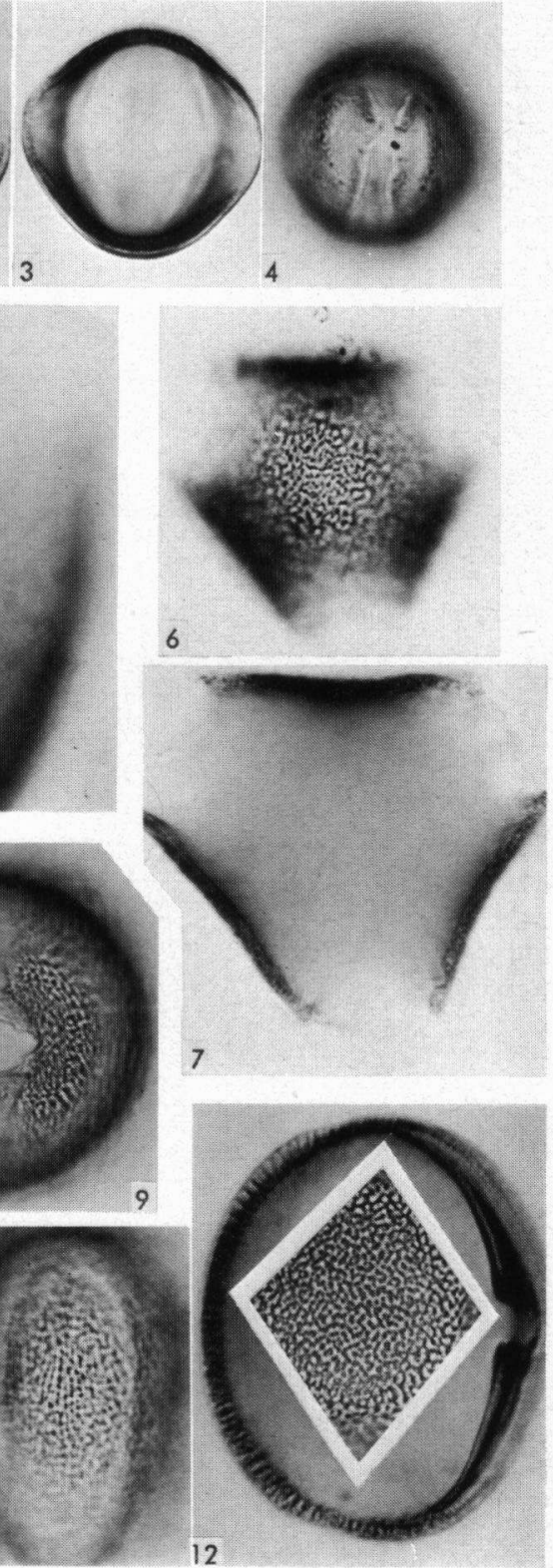

Pl. 2. 1-4, Logania-type (Logania ovata).-5-7, Spigelia-type. 5 (Spigelia leiocarpa). 6-7 (Desfontainia spinosa).-8-12 Gelsemium-type. 8-10 (Gelsemium rankinii). 11-12 Mostuea surinamensis. $\times 1000$. 


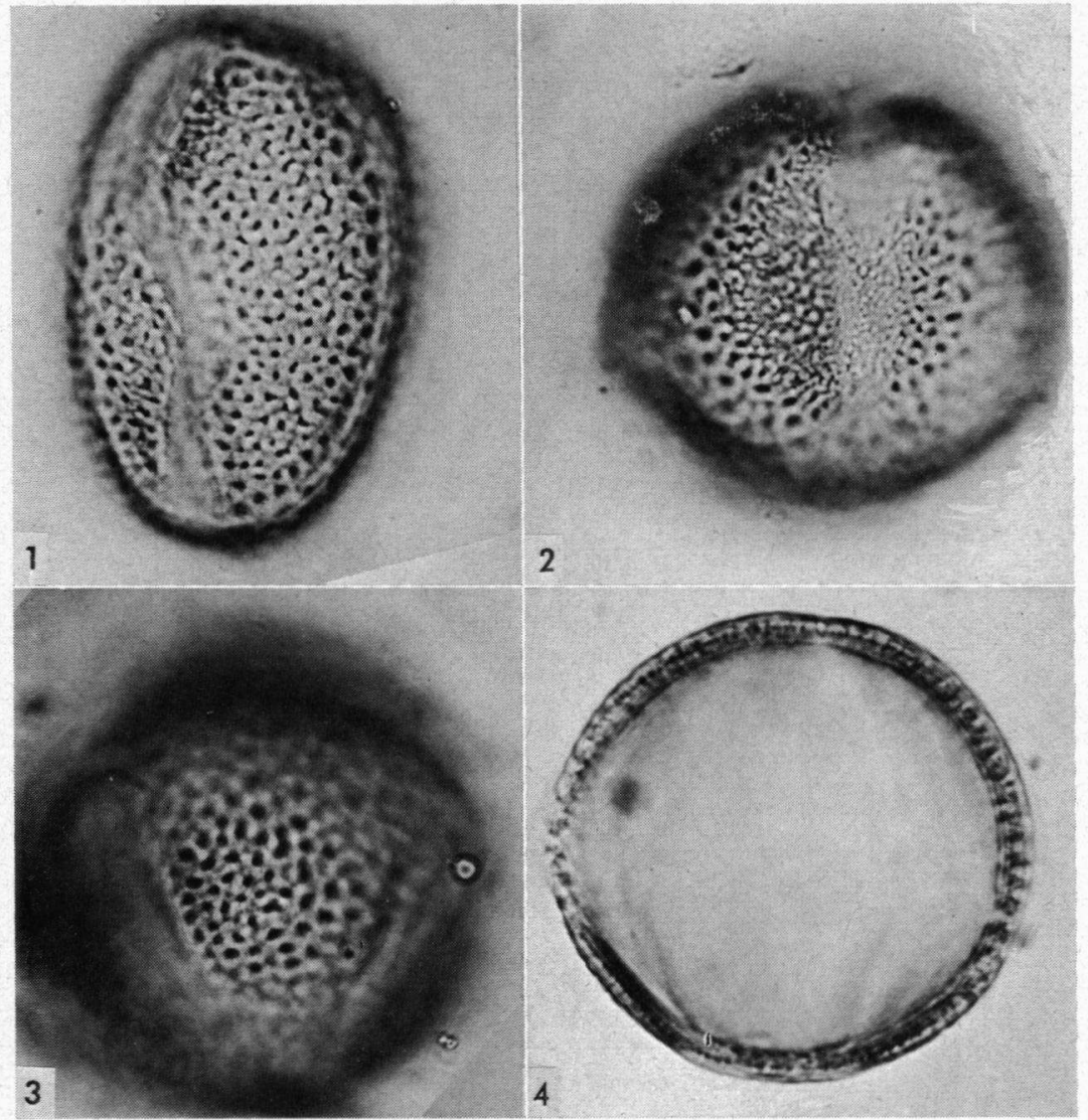

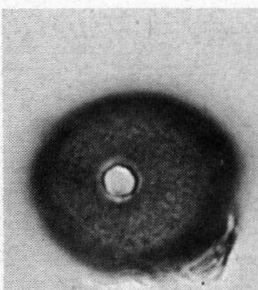

5
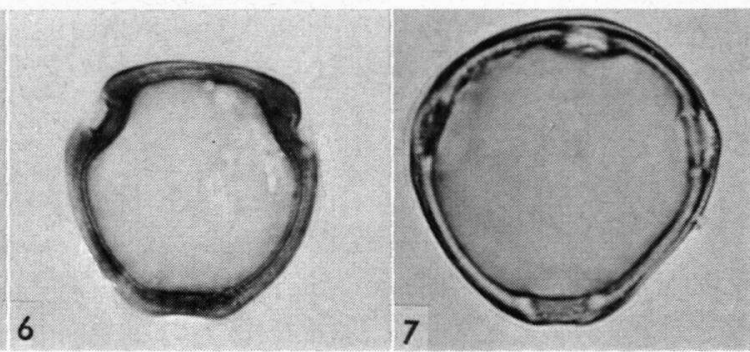

Pl. 3. 1-4, Retzia-type (Retzia capensis).-5-7, Geniostoma-type, Geniostoma subtype (Geniostoma rupestre). $\times 1200$. 

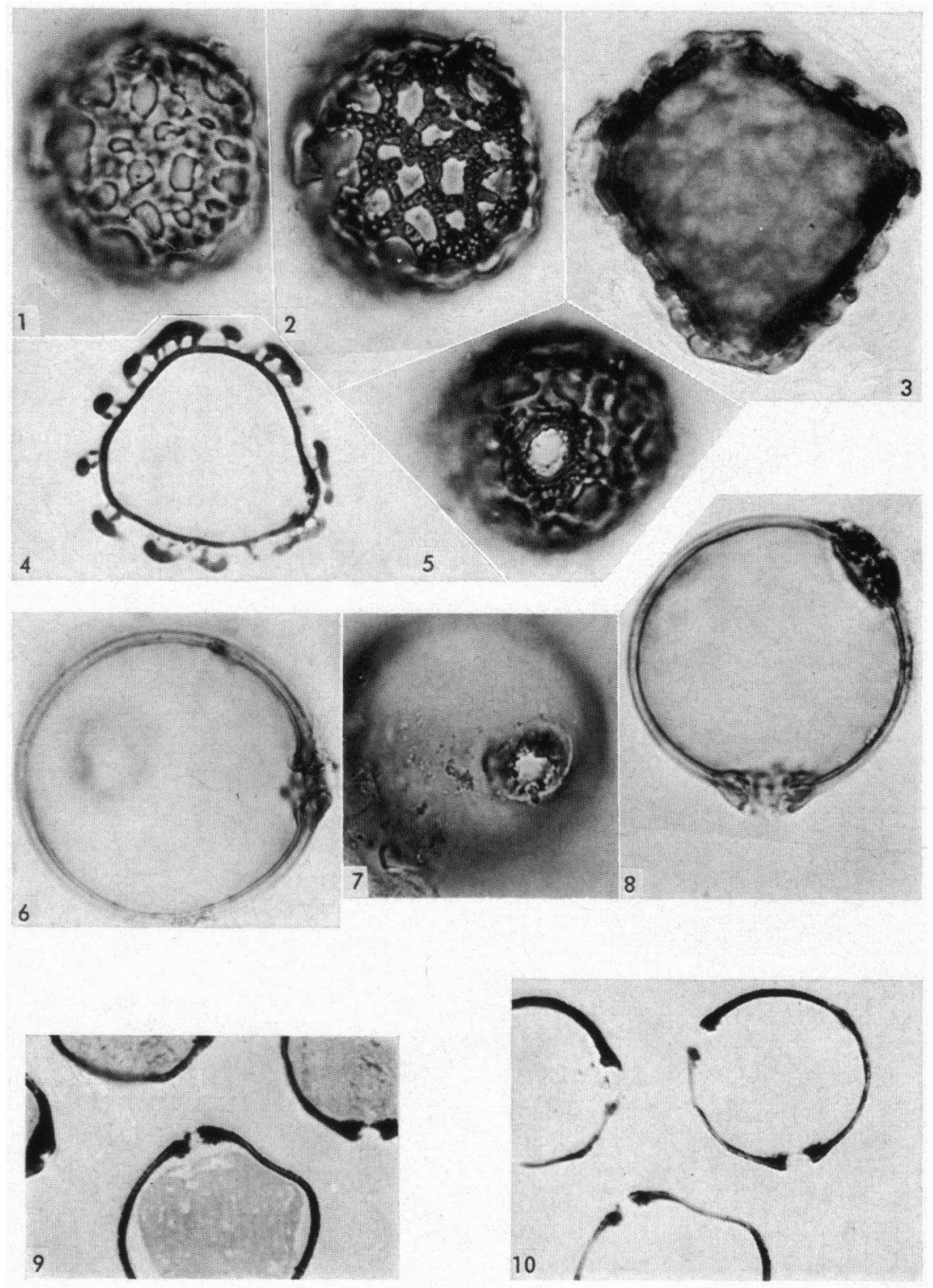

Pl. 4. 1-5, Geniostoma-type, Darbolia subtype (Labordia tinifolia).-6-10, Potaliatype. 6-8 (Potalia amara), 9-10 (Anthocleista nobilis), section about $0.5 \mu$ thick. $\times 1000$. 

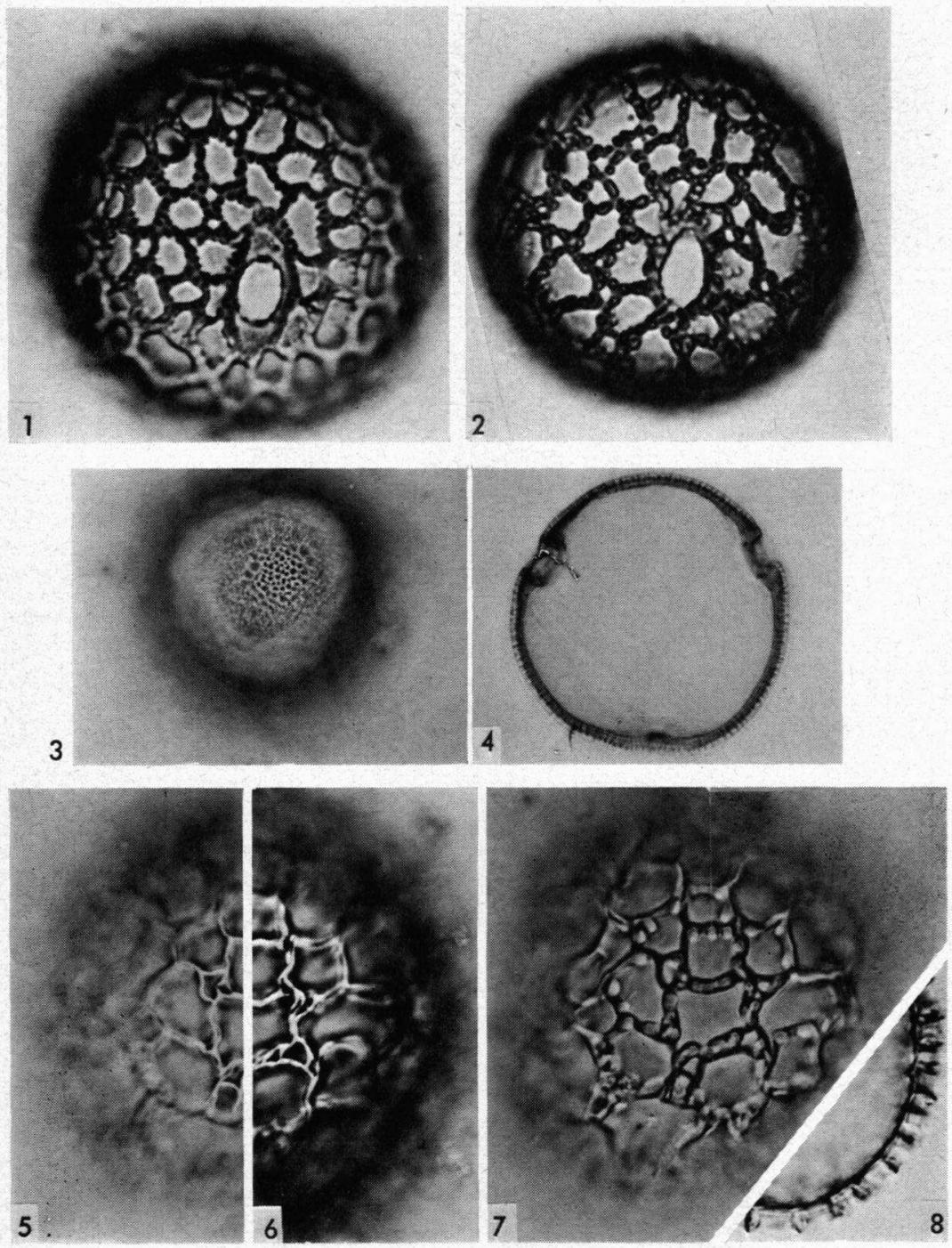

Pl. 5, 1-2, Fagraea ceilanica-type, Fagraea annulata subtype. 1, $(F$. annulata). 2, $(F$. carstensensis). - 3, Fagraea berteriana-type $(F$. berteriana). - 5-8, Fagraea ceilanicatype, Fagraea ceilanica subtype $(F$. ceilanica $) . \times 1100$. 

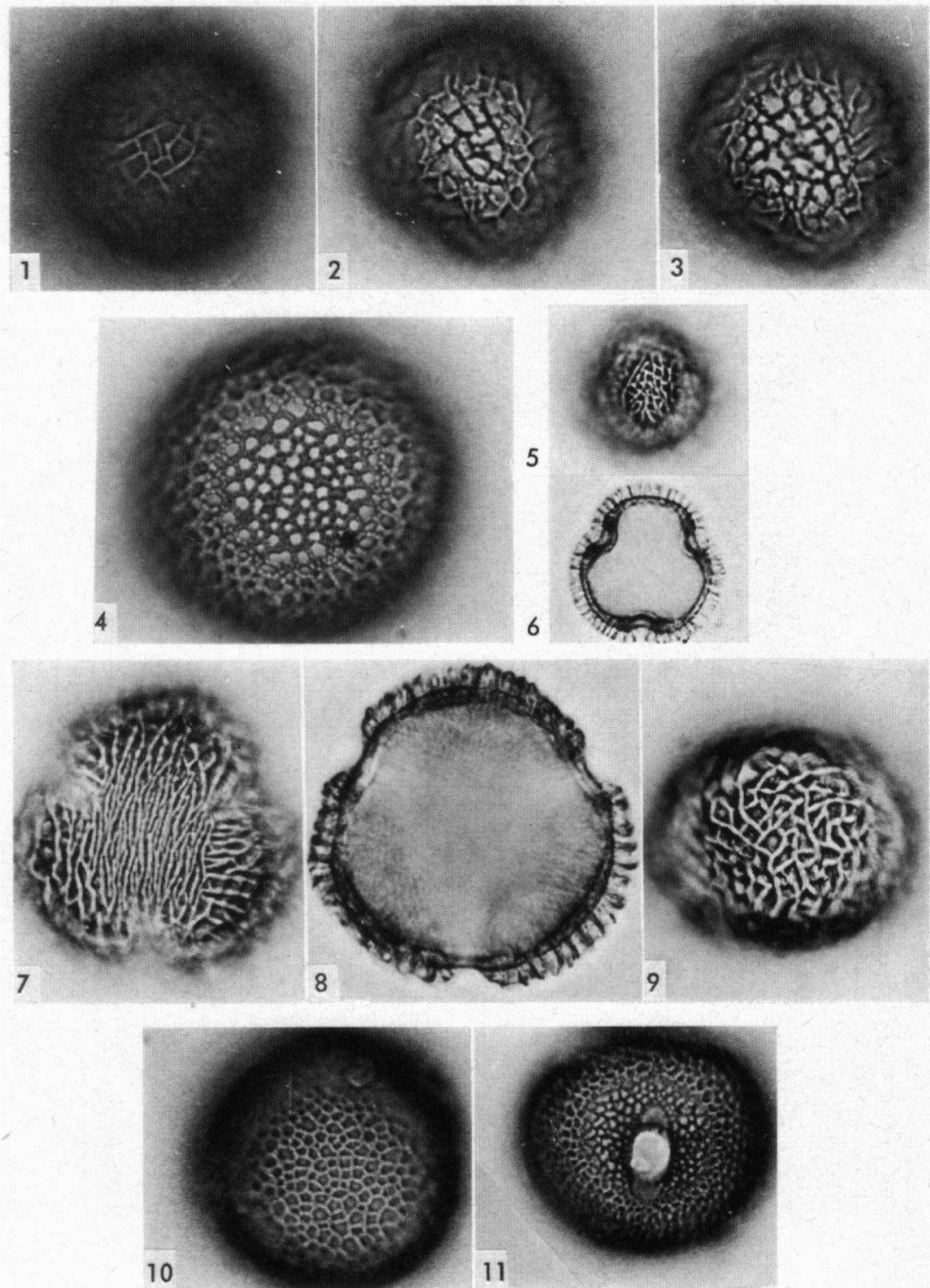

Pl. 6. 1-3, Fagraea fragrans-type, Fagraea crenulata subtype $(F$. crenulata). - 4, Fagraea ceilanica-type, Fagraea annulata subtype $(F$. eymae).-5-6, Fagraea fragrans-type, Fagraea fragrans subtype ( $F$. fragrans). - 7-9, Fagraea fragrans-type, Fagraea racemosa subtype $(F$. gracilipes).-10-11, Fagraea berteriana-type $(F$. salticola). $\times 1100$. 
POLLEN MORPHOL. AND TAXONOMY IN LOGANIACEAE
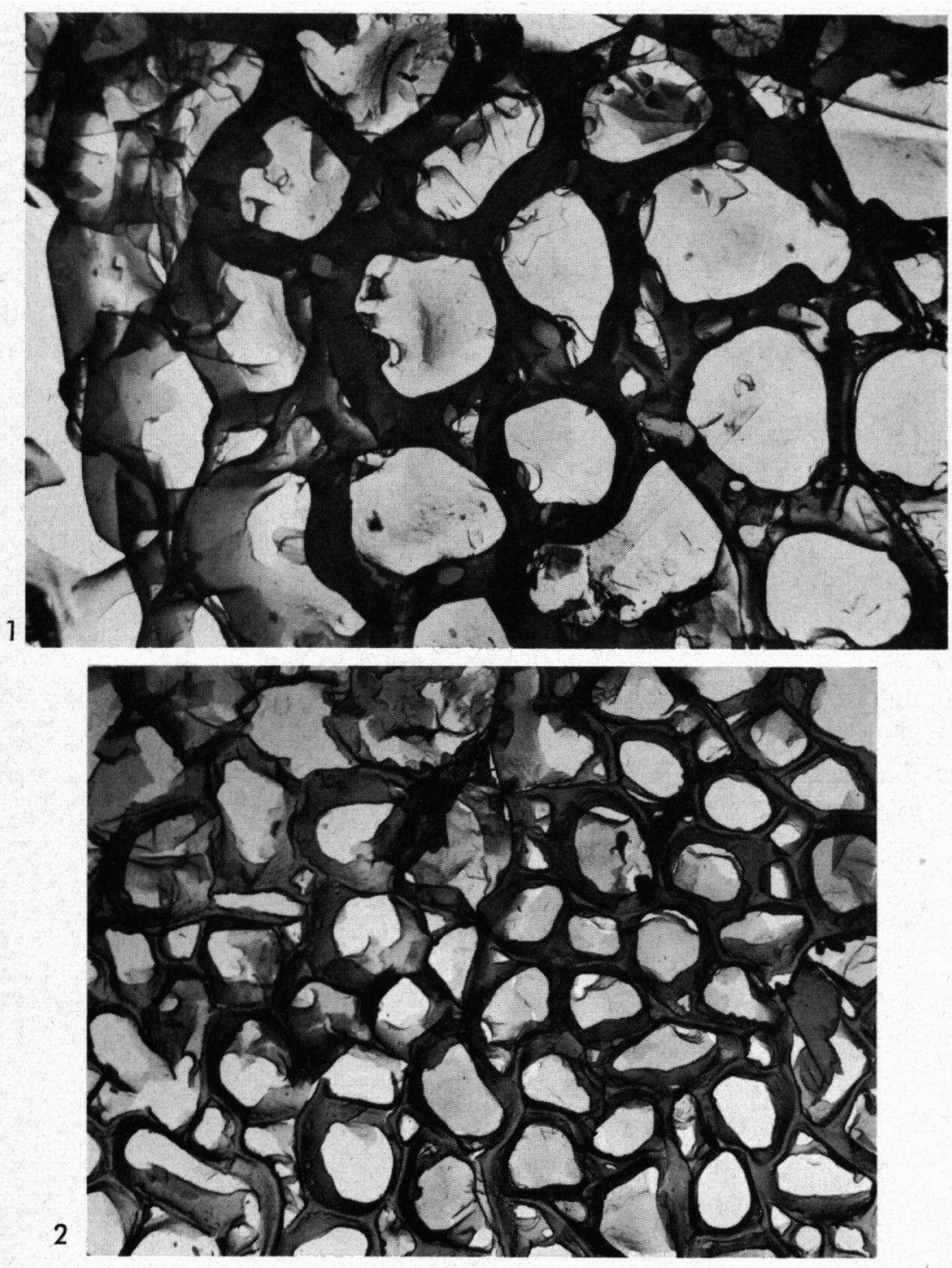

Pl. 7. Replicas. 1 (Fagraea ceilanica). $\times 2800,-2$ (Fagraea blumei). $\times 5200$. 


\section{A Systematic Commentary}

(P. W. Leenhouts)

Dr. Punt intentionally chose for his systematic-palynological study a family on which in recent years much systematic work has been done or is still in progress. First of all this makes it possible to compare palynological results with the sytematics as based upon the data derived from other disciplines, mainly gross morphology, and to have this done by a systematist specialized in that family. Furthermore, this had three more advantages for him: 1) he could be guided in selecting the taxa which deserved to be studied in the first place, 2) revised material was available, and 3) he could discuss his results with specialized taxonomists.

Before discussing the different palynological types in more detail, we may compare a scheme of their relationships as they are given in the preceding paper (Scheme I) with a scheme of the supposed relationships of the tribes based upon gross morphology (Scheme III). To facilitate the comparison, in Scheme II the first scheme has been "translated" into tribes.

Scheme I. Relationships of palynological types.

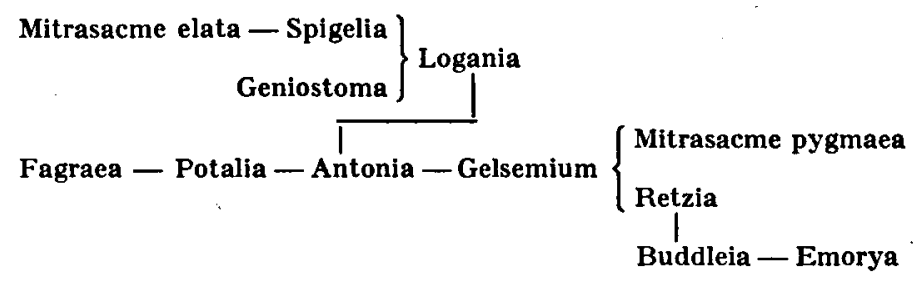

Scheme II. Relationships of tribes based upon palynology.

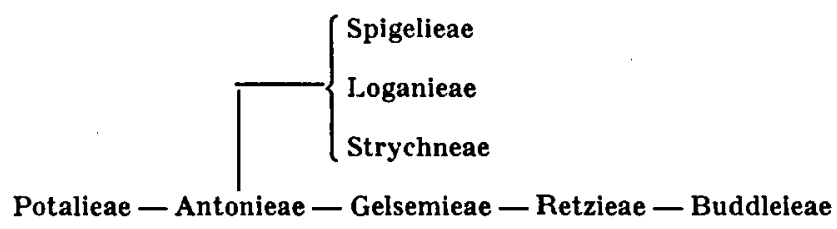


Scheme III. Relationships of tribes based upon gross morphology.

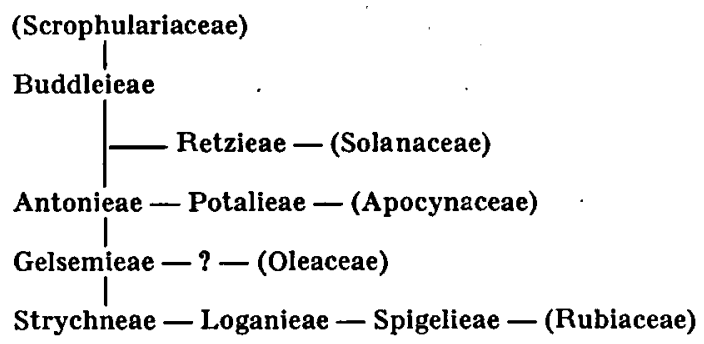

When comparing the scheme of the relationships of the tribes as based upon gross morphology (Scheme III) with that based upon palynology (Scheme II) the overall similarity is striking. In both the basic group comprises the Antonieae and the Gelsemieae, the Potalieae are connected with the Antonieae, the series StrychneaeLoganieae-Spigelieae is connected more on the side of the Gelsemieae. The Retzieae connect in both schemes the Buddleieae more or less with the further Loganiaceae, though in Scheme II the Retzieae are placed more towards the Gelsemieae, in Scheme III more towards the Antonieae.

\section{ANTONIA-TYPE}

The mutual connexion of the four genera included in the tribe Antonieae-viz. Bonyunia, Antonia, Norrisia, and Usteria-is confirmed by palynological evidence. Whereas palynologically Bonyunia is slightly different, Usteria is gross morphologically more isolated, showing several specializations in the flower. The resemblance of this pollentype with several other types of the Loganiaceae is well in accordance with the central position of this tribe in the family.

\section{BUDDLEIA-TYPE}

The Buddleia-type of pollen characterizes the Buddleieae apart from the genus Emorya. This is the first point of systematic interest, a discussion of which will be given, however, under the Emoryatype. The second point which deserves more attention is the position of the Buddleieae in relationship to the Loganiaceae proper on the one side, to the Scrophulariaceae on the other. I have discussed this position at some length some years ago (Leenhouts 1962). The conclusion was that morphologically as well as anatomically the Buddleieae clearly take a position between Loganiaceae and Scrophu- 
lariaceae. However, the delimitation against the Loganiaceae is more vague, its inclusion in that family seems more natural, than is the case in relation to the Scrophulariaceae. The genus Peltanthera, on the one end, shows distinct relationships with the Antonieae, Buddleia on the other side comes nearest to the Scrophulariaceae. For the systematist it is disappointing that palynology-like phytochemistry-clearly reveals a close relationship to the Scrophulariaceae and hardly any to the Loganiaceae. See, however, also under the Retzia-type.

The two subtypes are systematically unimportant.

\section{EMORYA-TYPE}

As alluded to already under the Buddleia-type, the fact that the genus Emorya is apparently characterized among all Buddleieae by a different-though related-pollentype is interesting. Emorya is a monotypic genus from southwestern North America. It is at least closely related to Buddleia, should possibly even be included in that genus judging from gross morphology. There is one palynological fact that may point in the same direction, however. Out of the several Buddleia species, studied by Punt-about half of which American-two (B. alpina and $B$. americana), both American species, show sometimes, resp. usually 4-colporate pollen, thus partly breaking down the differences between the two types. It is possible that if more American species of Buddleia would be studied palynologically, more of these cases could be found, and hence the demarcation between these two types would turn out to be less sharp.

\section{SPIGELIA-TYPE}

This type characterizes two out of four genera of the Spigelieae, viz. Spigelia and Polypremum, and the genus Desfontainia of uncertain position. According to Punt it is nearest related to the Logania type-to which among others belong Cynoctonum and part of Mitrasacme, the two other genera of the Spigelieae-and to the Mitrasacme elata type to which belongs another part of Mitrasacme. Palynological evidence hence distinctly supports the relationship between the Spigelieae and the Loganieae suggested in the third scheme though in detail there is a discrepancy between systematics and palynology.

Contrary to the great morphological resemblance between the 
Spigelieae and the Rubiaceae-Hedyotideae, the pollen of these two tribes are completely different.

Palynological evidence now strengthens the argumentation for the inclusion of Polypremum in the Spigelieae instead of in the Buddleieae, as was usually done. Likewise, palynological evidence is in favour of the inclusion of Desfontainia in the Loganiaceae-though inclusion in the Spigelieae seems out of question.

\section{Mitrasacme-ty PeS}

From a palynological point of view, Mitrasacme is doubtless one of the most interesting genera among the Loganiaceae. Though only six out of a total of about 40 species have been studied, these represent already four distinct types. They are the M. elata-type (distinctly related to the Spigelia-type), the Logania-type, the M. indica type (close to the Logania-type), and the M. pygmaea-type (related to the Gelsemium-type). There is no doubt that Mitrasacme has to be included in the Spigelieae and that it represents an entity taxonomically. As the genus is in urgent need of revision, hardly anything can further be said. Only can be suggested that $M$. elata may belong to another subgenus or section than the other species studied.

\section{LOGANIA-TYPE}

The genera showing this type belong to three different, though doubtless mutually related, tribes: the Strychneae (complete), the Loganieae (Logania), and the Spigelieae (Cynoctonum and at least one species of Mitrasacme). The palynological resemblance with the Mitrasacme indica-type, the Spigelia-type, and the Geniostomatype also reflect the closer connexion between these three tribes. Especially in this part of the family the palynological demarcations do not coincide with those based upon gross morphology.

\section{Gelsemium-Type}

Well in accordance with the conclusions derived from gross morphology, Gelsemium and Mostuea are also palynologically distincly closely related. The resemblance with the Antonia- and Logania-types is also in accordance with the supposed systematic relationships. 
RETZIA-TYPE

This type characterizes the monotypic tribe Retzieae. The position of the genus Retzia has been uncertain for a long time. Recently, Leeuwenberg (1964) included it in the Loganiaceae as a tribe of its own, related to both the Antonieae and the Buddleieae. It is very satisfying that palynological evidence favours its inclusion in the Loganiaceae, and even to some degree its exact place in this family. For the Retzia-type comes nearest to the Gelsemium-type-the Gelsemieae being distinctly related to the Antonieae-, the Buddleia type following at the second place. Moreover, this strengthens the position of the Buddleieae within the Loganiaceae. On the other hand, the differences in pollen between Retzia, resp. Metternichia and Sessea are in contrast to a relationship with the Solanaceae as also often suggested.

\section{Geniostoma-TYPe}

This type characterizes two out of the three genera of the Loganiaceae, Logania-which shows a certain similarity palynologicallybeing included under the Logania-type. These two genera are systematically intimately related; actually Labordia is hardly more than an isolated, in some characters more specialized offshoot of Geniostoma. The two subtypes are apparently hardly of any systematical importance.

\section{Potalia-type}

The Potalia-type and the Fagraea-types cover the genera Fagraea, Potalia and Anthocleista which together make up the tribe Potalieae. The Potalia-type is via Fagraea gardenioides and $F$. berteriana connected with the Fagraea berteriana-type which is the highest evolved one among the Fagraea-types. This position of the Potalia-type is in good accordance with the systematic affinities as Fagraea includes the doubtless most primitive members of the Potalieae, while Potalia and Anthocleista are clearly more specialized genera, especially as regards their flower characters.

The striking resemblance between Loganiaceae-Potalieae and Apocynaceae-Tabernaemontanae is not supported by palynology.

\section{Fagraea-types}

Palynologically, Mitrasacme and Fagraea appear to be the most interesting genera of the Loganiaceae. Whereas Mitrasacme is 
systematically as well as palynologically too insufficiently known to draw any conclusions, our knowledge of the genus Fagraea seems to justify a closer consideration. Twenty-five out of thirty-one species have been studied palynologically, and a recent taxonomical revision is available (Leenhouts 1962).

Parallel with the grouping into palynological types and subtypes and the "evolutionary trends" given by Punt in the main part of this paper, a grouping of the species on morphological grounds and some more "evolutionary trends" derived from gross morphology may precede a closer study of the systematic relationships.

The species of Fagraea can be grouped as follows:

elliptica, fragrans and probably umbelliflora, together making up the section Cyrtophyllum; possibly, there is some relationship between umbelliflora and gracilipes;

racemosa, the only species of the section Racemosae;

ceilanica, annulata (which shows also relationship to the berterianagroup), acuminatissima, tubulosa, ridleyi, blumei, fastigiata, possibly crenulata, truncata, tacapala, woodiana, longiflora, and carstensensis; auriculata, involucrata, macroscypha, and resinosa; this group is doubtless related to the previous one;

carnosa;

gardenioides, curtisii, and calcarea; this group is possibly related with the berteriana-group;

gracilipes (relationships possibly with umbelliflora and berteriana); eymae, salticola, bodenii, gitingensis, and berteriana; relationships possibly with annulata, the gardenioides-group, and gracilipes.

The "evolutionary trends" underlying the assumptions on primitive or advanced are:

1. tree $\rightarrow$ shrub or epiphyte; 2 . leafbase without auricles $\rightarrow$ with auricles (wings are possibly a transitional stage phylogenetically); 3. inflorescences many-flowered $\rightarrow$ few-flowered $\rightarrow$ flowers solitary; 4. inflorescences dichasial $\rightarrow$ umbellate or glomerulous; 5 . inflorescences dichasial $\rightarrow$ thyrsoid $\rightarrow$ racemose $\rightarrow$ spicate; 6. pedicels with one pair of bracteoles $\rightarrow$ without bracteoles; 7 . pedicels with one pair of bracteoles $\rightarrow$ with two pairs of bracteoles; 8 . bracteoles rather small and inserted halfway the pedicel $\rightarrow$ big, forming a kind 
of involucre around the calyx. Other probable trends are: 9. inflorescences terminal $\rightarrow$ axillary; 10 . stamens inserted directly on the corolla $\rightarrow$ inserted on a thickened ring; 11 . anthers about oblong $\rightarrow$ linear; 12. stigma undivided $\rightarrow$ bilobed.

Now we may have a closer look at the different groups of species in the light of the "phylogenetical" series mentioned above and of palynological evidence.

Sect. Cyrtophyllum represents doubtless the most primitive group in Fagraea. F. elliptica is primitive according to 11 of the criteria mentioned above, only the bracteoles being occasionally absent. $F$. fragrans seems to be slightly more advanced (inflorescences axillary, sometimes few-flowered, bracteoles sometimes absent). $F$. umbelliflora is distinctly more advanced in several characters. Furthermore, these species fit better in with the whole of the Loganiaceae-especially with the Antonieae-than the other groups. $F$. elliptica and fragrans are both widespread-throughout Malesia, resp. also in continental Asia-which may also account for relative primitiveness; $\boldsymbol{F}$. umbelliflora is a local endemic of New Guinea. All this is very well in accordance with palynological evidence: all three are characterised by $F$. fragrans-type pollen which is considered the most primitive type in the genus. This is especially satisfying as to $F$. umbelliflora as its inclusion in this section was provisional only. Moreover, its further relationship with $F$. gracilipes is also confirmed palynologically! The fragrans and gracilipes subtypes may be of less importance systematically.

$F$. racemosa, representing the monotypic section Racemosae, is, according to the trends cited above, relatively primitive. Only in its mostly shrublike habit and in the thyrsoid, racemose, spicate, or glomerulous inflorescences-in the last case rather few-flowered-is it more advanced. Its relatively wide geographical distribution-from SE. Asia to the Solomon Islands and northern Australia-also points to relative primitiveness. This is in accordance with palynology, as its pollen belong to the supposedly primitive $F$. fragrans-type.

The ceilanica group is the kernel of the section Fagraea. It seems too speculative and hardly of any use to try at a phylogenetic scheme within this group. Some of its species are about as primitive as F. elliptica and fragrans according to the above criteria, others show specializations mainly regarding shrublike or epiphytic habit, wings at the leafbase, few-flowered and glomerulous inflorescences, some- 
times reductions or specializations in the bracteoles, in one case insertion of the stamens on a ring ( $F$. annulata). First to be mentioned among the more primitive species are $F$. crenulata which will be discussed later, and $F$. blumei and, $F$. tacapala and $F$. ceilanica. $F$. blumei and ceilanica, both widespread, are doubtless closely related, and together constitute the base of the group. $F$. ceilanica is very variable, but can not be subdivided in well defined taxa; $F$. blumei is towards the east replaced by some taxa which show more advanced characters (ssp. plumeriaeflora, $F$. fastigiata, truncata, and tacapala). Palynologically, all species of this group have pollen of the $F$. ceilanica-type with the exception only of $F$. crenulata the pollen of which are included as crenulata subtype under the $F$. fragrans-type. $F$. crenulata is a rather primitive, relatively widespread species, which probably had better not be included in the ceilanica group. Furthermore, the subdivision of the ceilanica-type into two subtypes is of interest. Most of the species show the ceilanica subtype, $F$. annulata and carstensensis make up the annulata subtype. As a matter of fact, a palynological series can be made: $F$. ceilanica-carstensensis-annulata-eymae-berteriana. This series reflects surprisingly well the main systematic relationships. $F$. carstensensis, annulata and eymae are all rare local endemics of western New Guinea, where $F$. ceilanica has developed some related races. The position of $F$. carstensensis was morphologically not very clear; $F$. annulata is doubtless closely related to $F$. ceilanica, different, however, by the insertion of the stamens on a ring, a character pointing to the berteriana group; $F$. eymae and berterinana belong to the latter group and will be further discussed there. Here again the agreement between systematic conclusions derived from palynology, resp. gross morphology, is very satisfactory.

The auriculata group is a very coherent one. It consists of the widespread $F$. auriculata, and three Bornean endemics. The relationship seems to be with the ceilanica group, more especially with the alliance of $F$. blumei. The auriculata group is more advanced as a whole, however, by the tendency towards a, solitary flower, towards two or three pairs of bracteoles, forming an involucre around the calyx, by the in principle epiphytic or shrublike habit, and by the auricles at the leafbase (missing in $F$. resinosa, possibly secondary?). Palynologically, all four species show the ceilanica subtype of pollen, thus stressing the relationship with the ceilanica group. 
$F$. carnosa seems systematically rather isolated. Morphologically it is rather advanced in some characters (epiphyte, flowers solitary). It is relatively widespread (Lower Burma and West Malesia). Palynologically, it is included in the advanced berteriana type. There seems to be no reason, however, to look at the berteriana group-to which belong the other species with this type of pollen-for closer relationships.

The gardenioides group, distinctly cohering, shows no distinct closer relationships to any of the others. Only the presence of linear anthers and of a sometimes bilobed stigma may point to the berteriana group. This resemblance, up till now hardly taken seriousthe gardenioides group being West Malesian till Borneo, the berteriana group East Malesian, though including the Philippines-is now strengthened by palynology. Only the pollen of $F$. gardenioides ssp. borneensis are known; they belong to the relatively advanced Potalia-type, show a distinct resemblance to $F$. berteriana pollen, however!

$F$. gracilipes is a rather isolated, in most characters relatively primitive species. Its area of distribution is fairly wide-from New Guinea and NE. Australia to Fiji; within this area about 5 local races are more or less distinguishable. This too speaks well for relative primitiveness. This is confirmed by its pollen which belong to the gracilipes subtype of the fragrans-type. Moreover, this strengthens the suggested relationship between $F$. gracilipes and umbelliflora.

The berteriana group is again very coherent. Apart from $F$. eymae -which seems to be related to $F$. salticola, however-they all show the probably advanced characters of a thickened ring on which the stamens are inserted (furthermore known only from $F$. annulata), linear anthers (furthermore in $F$. gardenioides), and a distinctly bilobed stigma (a tendency to which is also found in $F$. woodiana, gardenioides, and gracilipes). Furthermore, $F$. berteriana lacks bracteoles. Apart from $F$. gitingensis (Philippines and Moluccas) and $F$. berteriana (New Guinea, NE. Australia, and widely distributed in the SW. Pacific), it are endemics of New Guinea. F. berteriana shows the most advanced characters, and, though wide, its area of distribution makes also the impression of being young (for argumentation see Leenhouts 1962). These systematical reflections are fully supported by palynological evidence. All four species known ( $F$. gitingensis is unknown) have $\mathrm{F}$. berteriana-type pollen, and, as alluded to already under the ceilanica group, this type is connected 
with the $F$. ceilanica-type via a series $F$. ceilanica-carstensensisannulata-eymae-berteriana. In how far the close similarity between $F$. berteriana pollen and $F$. gardenioides pollen-the latter representing the most advanced Potalia-type-reflects real close relationship can hardly be said; as $F$. gardenioides shows also the linear anthers and a tendency towards the bilobed stigma of the berteriana group, and as $F$. gardenioides reaches to Borneo, the berteriana group to the Philippines, this is far from impossible. Then, however, $F$. gardenioides may represent a rather early offshoot.

Summarizing, the agreement between palynology and hitherto accepted systematics based nearly exclusively upon gross morphology is surprisingly good. Of course, this is a great satisfaction for the students of both disciplines. The fact that (in Fagraea) even detail problems in systematics could partly be solved thanks to palynological evidence, may be exceptional, but it also shows the value of studying the pollen of as many species of a genus as possible. This will only be possible, however, if somebody is working systematically in the taxon concerned or if a recent revision of the taxon is available.

Rijksherbarium, Leiden, Netherlands

\section{REFERENCES}

Bruce, E. A. \& Lewis, J. 1960. Loganiaceae in Flora of Tropical Africa.

Cranwell, L. W. 1942. New Zealand Pollen Studies. - Recl. Auckl. Inst. Mus. 2: 280-308.

Duncan, W. H. \& Jong, D. W. DE. 1964. Taxonomy and heterostyly of North American Gelsemium (Loganiaceae). - Sida 1: 346-357.

Erdtman, G. 1943. An introduction to Pollen Analysis. Waltham. Mass.

- 1948. Algunos aspectos de la palinologia. - An. Inst. Esp. Edaf. 7 (2): 17.

- 1952. Pollen Morphology and Plant Taxonomy. Angiosperms. - Stockholm and Walth., Mass.

- 1957. Pollen and Spore Morphology and Plant Taxonomy. Gymnospermae, Pteridophyta, Bryophyta. - Stockholm.

- 1960. The acetolysis method. A revised description. - Svensk bot. Tidskr. 54: 561-564.

F feGri, K. \& Iversen, J. 1964. Textbook of modern pollen analysis, ed. 2. Copenhagen.

Gadella, T. W. J. 1961. The chromosome number of Anthocleista djalonensis Chev. - Acta bot. neerl. 10: 107-108. 
- 1962. Some cytological observations in the Loganiaceae. - Acta bot. neerl. 11: 51-55.

- 1963. Cytological studies in the Loganiaceae. - Akad. nederl. Wet. Proc. Ser. C. 66 (3).

Gandoger, M. 1923. La famille des Strychnacées. - Bull. Soc. bot. France 70: $919-921$.

Hutchinson, J. 1959. Families of Flowering Plants ed. 2. Vol. I. - Oxford. IkUse, M. 1956. Pollen grains of Japan. - Tokyo.

KLetT, W. 1924. Umfang und Inhalt der Familie der Loganiaceae. - Bot. Arch. 5: 312-338.

Leenhouts, P. W. 1962. Flora Malesiana 1 (6): 293-387.

- 1962 (a). Flora Malesiana Precursores XXXIIl. Loganiaceae. - Bull. Jard. bot. Brux. 32: 417-458.

Leeuwenberg, A. J. M. 1961. The Loganiaceae of Africa. I. Anthocleista. Acta bot. neerl. 10: 1-53.

- 1961 (a). The Loganiaceae of Africa. II. A revision of Mostuea Didr. Meded. LandbHoogesch. Wageningen 61 (4): 1-31.

- 1963. The Loganiaceae of Africa. V. Usteria Willd. - Acta bot. reerl. 12: 112-118.

- 1964. The Loganiaceae of Africa VI. Retzia. - Acta bot. neerl. 13: 333339.

Mohrbutter, C. 1937. Embryologische Studien an Loganiaceae. - Planta 26: $64-80$.

Moore, R. J. 1947. Cytotaxonomic studies in the Loganiaceae I. Chromosome numbers and Phylogeny in the Loganiaceae. - Amer. J. Bot. 34: 527-538.

- 1960. Cytotaxonomic notes on Buddleia. - Amer. J. Bot. 47: 511-517.

Philips, E. P. 1946. The genus Chilianthus Burch. and Buddleia Linn. - Jl S. Afr. Bot. 12: 113-114.

Punt, W. 1962. Pollen Morphology of the Euphorbiaceae with special references to taxonomy. - Wentia 7.

Selling, O. H. 1947. Studies in Hawaiian Pollen Statistics. Part II. Loganiaceae, 287-290. - Spec. Publ. Bishop Mus. 38.

SherfF, E. E. 1939. Genus Labordia. - Field Mus. Nat. Hist. 17: 477-846.

Solereder, H. 1892. Loganiaceae in Engler und Prantl, Die nat. Pflanzenfam. 4 (2): 29-50.

Verdoonn, I. C. in Dyer, R. A., Codd, L. E. and Rycroft, H. B. 1963. Loganiaceae. - Flora of Southern Africa 26.

Wang. 1960. Pollen morphology of Chinese Plants. (Copy in the library of the Palynological Laboratory, Solna). 